\title{
NOTE
}

\section{CURFEW ORDINANCES AND THE CONTROL OF NOCTURAL JUVENILE CRIME *}

\section{INTRODUCTION}

The increased public concern regarding the frequency and gravity of juvenile crime since the termination of the second world war ${ }^{1}$ has given impetus to state and municipal legislation expanding police power to cope with the problem. ${ }^{2}$ One response has been the enactment of municipal ${ }^{3}$ and, in some instances, state ${ }^{4}$ curfew legislation for juveniles. ${ }^{.}$In general,

* The research for this Note was financed by the annual grant to the University of Pennsylvania Law School for studies on Law Enforcement and Individual Liberty. This grant is provided by Jacob Kossman, Esq., of the Philadelphia Bar, in memory of the late Justice Wiley Rutledge.

The Law Review wishes to express its appreciation to Inspector Harry G. Fox, Philadelphia Police Department, Juvenile Division, Raymond Kitty, Assistant City Solicitor, Dr. E. Preston Sharp, Executive Director of the Philadelphia Youth Study Center, and to the many other persons whose generous cooperation aided in the completion of this study.

1. The number of persons arrested in the United States under eighteen years of age increased from 31,750 in 1948 to 234,474 in 1956. During the same period the percentage of arrests of persons under eighteen years of age as compared to total arrests increased from $4.2 \%$ to $11.3 \%$. Changes in some of the more serious crimes are: 1948

\begin{tabular}{|c|c|c|c|c|}
\hline & & \\
\hline & $\begin{array}{l}\text { No. of } \\
\text { persons } \\
\text { arrested } \\
\text { under } 18\end{array}$ & $\begin{array}{l}\text { Percentage } \\
\text { of total } \\
\text { arrests }\end{array}$ & $\begin{array}{l}\text { No. of } \\
\text { persons } \\
\text { arrested } \\
\text { under } 18\end{array}$ & $\begin{array}{c}\text { Percentage } \\
\text { of total } \\
\text { arrests }\end{array}$ \\
\hline $\begin{array}{l}\text { Criminal Homicide } \\
\text { Robbery } \\
\text { Assault } \\
\text { Rape } \\
\text { Larceny } \\
\text { Auto Theft }\end{array}$ & $\begin{array}{r}208 \\
1,121 \\
1,157 \\
773 \\
6,093 \\
3,030\end{array}$ & $\begin{array}{r}3.1 \\
5.4 \\
2.0 \\
8.1 \\
8.9 \\
17.1\end{array}$ & $\begin{array}{r}213 \\
2,692 \\
7,531 \\
840 \\
46,477 \\
18,622\end{array}$ & $\begin{array}{r}6.2 \\
24.7 \\
7.3 \\
18.3 \\
50.4 \\
66.4\end{array}$ \\
\hline
\end{tabular}

FBI, 19 Uniform Crime Reports 117 (1948); FBI, 27 UnIform Crime Reports 110 (1956).

2. See American Municipal. Assoctation, How Cittes Control Juvenile DeLINQUENCX 33-35 (1957).

3. Appendix $A$ at p. 102 infra.

4. See text and notes at notes 91-97 infra.

5. Historically, curfews can be traced at least as far back in history as William the Conqueror. 8 Encyclopedia Americana 306 (1957 ed.). In the pre-Civil War United States, curfew laws existed in southern towns indicating the times at which slaves were required to be off the streets. Ibid. Curfew legislation aimed at juveniles received its first substantial support in the latter portion of the nineteenth century. President Benjamin Harrison then called the curfew "the most important municipal regulation for the protection of the children of American homes, from the vices of the street. . ." 8 ENCYCLOPEDIA AMERICANA 306 (3d ed. 1925). In 1884 Colonel Alexander Hogeland, "the Father of the curfew law," urged the adoption of curfew ordinances at the National Convention of the Boys and Girls Home Employment Association. Ibid. His recommendations were heeded in many instances and received substantial support in the periodicals. See Townsend, Curfew for City Children, 163 N. AM. REv. 725 (1896). But see Buch, Objections to a Children's Curfew, 164 
curfew ordinances prohibit juveniles from remaining in public places or on the streets ${ }^{6}$ after a stated hour in the evening, ${ }^{7}$ and provide penalties for repeated violations to be imposed on the juvenile ${ }^{8}$ and/or on those legally responsible for the conduct of the juvenile. ${ }^{9}$ The purpose and justification of this legislation is ultimately to reduce juvenile crime, but its efficacy and social desirability are matters of vigorous dispute..$^{10}$

Advocates of a curfew, aside from agreement on the unassailable community objective of curbing juvenile criminal activity, are often as far apart from each other in their reasons for support of the measure as they are from those who oppose it. To some the curfew is an experiment, worth trying as a last resort where all other measures have apparently failed. To others the curfew is looked upon as a panacea, the logic of their argument being that nocturnal juvenile crime must necessarily be eliminated when children are constrained by the threat of legal sanction to remain at home. Some persons subscribe to the view that juveniles ought to be at home at night regardless of their individual dispositions to do wrong, and that therefore the curfew makes law of what is morally right. Similarly, the curfew is thought by some to promote family life by encouraging children to be at home. Undoubtedly there is some element of truth in each of these asserted justifications, but at best they are inconclusive and serve only to shift the focus of attention from more basic legislative considerations such as whether the curfew can be enforced, the opportunities for police abuse in enforcement, how much criminal activity is likely to be affected by the ordinance, what is the prevalence of noctural juvenile crime, and what sacrifices are being required of individuals not

N. Ax. REV. 381 (1897). At that time urban juvenile crime was attributed to the lack of parental responsibility, thought to exist chiefly among the large numbers of immigrant families then entering the United States. Townsend, supra at 725 . Curfews were envisaged as a device to curb unwholesome juvenile activity, primarily by enforcing parental responsibility on these families. Ibid. By the turn of the century approximately three thousand municipalities and villages had adopted such ordinances. 8 ENCYCLOPEDIA AMERTCANA 306 (1957 ed.). Interest in curfews then waned until the second world war. National Institute of Municipal Law Officers, MuniciPALITIES AND THE LAW IN Action 58 (1944). With parents in the armed forces or working in war industries, often on night shifts, and with the influx of servicemen into urban areas, control of juveniles became an increasingly difficult task. Resultant wartime curfews attempted to prevent juveniles from roaming the streets or loitering in public places. However, even under the strained conditions of the wartime emergency, curfew legislation was not without its critics. WELCE, THE CURFEW-Is IT a Desirable Measure? (U.S. Dep't of Labor, Children's Bureau, 1943). Conclusion of the war did not produce any decline in the incidence of juvenile crime, but rather occasioned a marked increase in delinquency, see note 1 supra, with a concomitant increased interest in curfew measures.

6. See text and notes at notes 48-57 infra.

7. See text and notes at notes $27-42$ infra.

8. See text and notes at notes $65-75$ infra.

9. See text and notes at notes 76-90 infra.

10. E.g., letter from Elizabeth B. Brown, Police Department, Portland, Oregon, Oct. 8, 1957, expressed favor toward curfews. Letter from Oscar F. Brewer, Police Department, Duluth, Minnesota, Aug. 20, 1957, expressed opposition toward curfews. These and all other communications cited in this Note were sent to the University of Penusylvania Law Revieze and are on file in the Biddle Law Library, University of Pennsylvania Law School. 
likely to engage in anti-social behavior. More sympathy is deserving to those curfew supporters who seek justification on the narrower ground that it is a necessary police device designed to control nighttime accumulation of juveniles in public places with its attendant risk of mischief.

Opponents of the curfew urge a variety of objections to curfew enactments, emphasizing an asserted improbability of its success. Primarily, they contend that the peak of juvenile criminal activity is in the early hours of the evening, before the time at which curfews usually go into effect. They argue that only a small portion of the juvenile population engages in criminal activity, and that the curfew is a shotgun approach, encroaching on the many who are innocent to control the dissident few. They stress further that effective enforcement of a general curfew is well beyond the physical capabilities of existing police forces. Finally, they point to the tendency of a curfew to shift the focus of attention from other more immediate problems of delinquency. ${ }^{11}$ But despite this vigorous protest curfew measures have been adopted in many of the metropolitan areas of the United States.

In an attempt to shed some light on the problem this Note has as its purpose the determination of (1) the prevalence of curfew legislation; (2) the conduct proscribed, the penalties imposed and the persons held responsible; (3) the judicial administration of the curfew in Philadelphia (where personal observations were made); (4) the likelihood that the curfew achieves the purposes ascribed to it; and (5) the constitutional validity of such ordinances. The data presented in this Note were gathered between June and September 1957.

\section{The Ordinances Analyzed}

\section{A. The Prevalence of Juvenile Curferw Ordinances}

In an effort to determine the prevalence of juvenile curfew ordinances throughout the United States, questionnaires were sent to the chiefs of police of 109 cities with populations over 100,000 persons. ${ }^{12}$ Information was requested as to whether a curfew ordinance existed in the particular city, and, if so, the terms of such ordinance and specified results achieved thereunder. Responses were received from 103 cities ${ }^{13}$ representing 94.5 per cent of those contacted. Fifty-seven ( 55.3 per cent) of the reporting cities had curfew ordinances in effect and forty-six (44.7 per cent) did not.

11. Many of these arguments are made with respect to the Philadelphia curfew ordinance and are set forth in PHILAdELPHIA District Health and Weifare Councis, Statement on CuRFew (Dec. 4, 1954).

12. The list of cities surveyed is found in International City Manager's Assoctation, Municipal Year Book 523-70 (1956). This list was based on the census of 1950 .

13. Appendix A at p. 102 infra more fully describes the scope of this survey. Except where indicated the information reported in this section was compiled from letters to the University of Pennsylvania Laz Review from police officials of the several municipalities. 
Of the reporting cities without curfews thirty-three neither offered an explanation for their absence nor indicated whether future adoption was anticipated. While generalization from the remaining responses is difficult, some of the reasons advanced for non-adoption may have general application. Four ${ }^{14}$ of the remaining thirteen cities stated merely that the delinquency problem was not so severe as to warrant such an enactment. ${ }^{15}$ Two cities, Fort Wayne, Indiana and Houston, Texas, had not enacted curfews because they believed their respective state statutes defining juvenile delinquency included conduct normally encompassed by a curfew, making further enactments on their part unnecessary. ${ }^{16}$ Washington, D. C. and Kansas City, Kansas reported that the adoption of a curfew ordinance was under consideration. ${ }^{17}$ On the other hand, South Bend, Indiana abandoned a proposal to adopt a curfew because "too many people [were] against such a law." 18 An interesting situation was reported in both Baton Rouge, Louisiana and Atlanta, Georgia where the police departments admitted to the enforcement of an "unofficial curfew," even though the councils of these cities had not enacted such legislation. The police departments of both municipalities established "curfew hours." The departments outlined their practices under the "curfew" as follows: if children are found on the streets after the "curfew" hour, the contacting police officer records their names and addresses and those of their parents, as well as their reasons for being away from home. This information is forwarded to the appropriate juvenile authorities and is used only for informational purposes in the event that the child subsequently becomes involved in a juvenile offense. Occasionally the parents are contacted and their cooperation is enlisted in the control of their children. ${ }^{19}$

Nine of the fifty-seven cities which have curfew ordinances reported that they were not enforced. ${ }^{20}$ Generally, non-enforcement was attributed to the fact that at the time of inquiry juvenile delinquency problems were at a level that obviated the need for enforcement. Youngstown, Ohio,

14. Jersey City, New Jersey; Oklahoma City, Oklahoma; Scranton, Pennsylvania; Providence, Rhode Island.

15. Miami, Florida had a curfew ordinance which was recently declared unconstitutional. Riley v. City of Miami, Chancery No. 198087, Cir. Ct. of 11th Cir. of Fla., April 5, 1957. The constitutionality of curfew ordinances is considered at notes 180-91 isifra.

16. State legislation in the curfew area is discussed in text and notes at notes 9197 infra.

17. Louisville, Kentucky reported that the members of the law enforcement agencies of the community would welcome the passage of a curfew ordinance.

18. A curfew ordinance should not be enacted "unless considerable sentiment in favor is found to exist among the better classes of citizens in the community, and especially among the school and church leaders." AmErican Municipal Assoctation, InFormation Mearorandun No. 48-2-CuRfew Ordinances (March 19, 1948).

19. The Baton Rouge curfew goes into effect at 11:00 p.m. and that of Atlanta at midnight. No exceptions are made by the police in Atlanta and the curfew is enforced against all persons below eighteen years of age. No data on these latter points was received from Baton Rouge.

20. Montgomery, Alabama; Rockford, Illinois; Shreveport, Louisiana; Grand Rapids, Michigan; Newark, New Jersey; Syracuse, New York; Youngstown, Ohio; Chattanooga, Tennessee; Spokane, Washington. 
however, explained its failure to enforce the existing curfew on the ground that it was difficult to enforce and imposed added burdens upon the police department. $^{21}$

\section{B. Curfere Provisions}

Forty-eight municipalities with populations over 100,000 persons reported having curfew ordinances which were enforced. These generally varied in form according to the age group included, the curfew hours, the conduct prohibited, the conduct excepted, and the degree of responsibility placed on the minor, the parent and other persons. This section will analyze. the variations with a discussion, wherever feasible, of the rationale and implications of each.

\section{Age Groups of Minors Subject to Curfews}

All of the ordinances submitted by cities participating in the survey designated a specific age group subject to the curfew. ${ }^{22}$ Although in most instances no distinction as to age is made between males and females, two cities so provide. ${ }^{23}$ The following chart presents a summary of the age groups subject to the ordinances examined.

TABLE I

Age of Children Subject to Curfew in Cities With Populations Larger Than 100,000

$\begin{array}{cc}\text { Persons } & \text { Number } \\ \text { Under } & \text { of Cities } \\ 14 & 2 \\ 15 & 4 \\ 16 & 13 \\ 17 & 9^{24} \\ 18^{25} & 17^{26} \\ 21 & 3\end{array}$

21. This objection is often advanced by opponents of curfews. The reply that is made is that rigorous curfew enforcement ultimately reduces juvenile delinquency and hence lessens the work load of police. Experience does not support this reply. See text at notes $173-78$ infra.

22. Some smaller municipalities with less carefully drawn ordinances do not designate a specific age group, but use the word "minor" instead. While such a vague ordinance may lead to confusion on the part of police and children alike, they are generally interpreted as applying to persons under 18 years of age, although the legal age of minority is generally considered to be 21 . See Colorado Munictpal League Ordinance Bull., AN Analysis of Curfew Ordinances in Colorado (1956).

23. Buffalo, New York restricts males under 12 years of age and females under 14. The Peoria, Illinois ordinance covers males under 21 years of age and females under 18. These ordinances have been entered in Table 1 in the highest age group subject to the respective curfews.

24. The Philadelphia curfew ordinance follows the majority for its population group, its age group being minors under the age of 17 years.

25. San Francisco, California has an additional provision in its ordinance prohibiting three or more persons under 21 to congregate or engage in any sport or make any noise on any public street from 8:00 p.m. to daylight.

26. The curfew ordinance presently in force in Gary, Indiana covers children under 15 years of age. However, an amendment thereto which has passed two readings of council at the time of writing raises the age to children under 18 . 


\section{Hours of Curfew}

The curfew ordinances exhibit no consistency in the designation of curfew hours. The effective curfew hours range from 8:00 p.m. ${ }^{27}$ to 12 midnight. ${ }^{28}$ Most ordinances designate a specific time when the curfew is lifted, ranging from 3:00 a.m. ${ }^{29}$ to $6: 00$ a.m. ${ }^{30}$ while others use a term such as "sunrise" 31 or "daylight." 32 Three ordinances, however, do not designate any time for the termination of the curfew. ${ }^{33}$ Such an ordinance is the product of poor draftsmanship as it serves only to create confusion on the part of both law enforcement officers and the public and permits legal attack on the validity of the ordinance on the ground of vagueness. ${ }^{34}$

The time limitations in most curfews are constant throughout the week, do not vary during the year, and apply equally to all age groups subject to the curfew. However, three variations from the general pattern, existing singly or in combination, can be found: age-time variations, ${ }^{35}$ seasonaltime variations, ${ }^{36}$ and weekend-time variations. ${ }^{37}$ In the age-time variation, different curfew hours are imposed on various age groups: the older the child the later his curfew begins. ${ }^{38}$ This provision evidently is based on the assumption that it is more reasonable to require a younger child to be home at an earlier hour than an older child, particularly since a younger child is less likely to have legitimate business at night. However, it would seem that a basic disadvantage to this subclassification is the

27. New Haven, Connecticut.

28. Milwaukee, Wisconsin.

29. New Haven, Connecticut. The hours of curfew in New Haven are from 8:00 p.m. to 3:00 a.m. The efficacy of such provisions is questionable. If the juvenile delinquency problem is so acute as to warrant an 8 o'clock curfew it would seem that permitting children to be on the streets after 3:00 a.m. would not further the aims of curfew enactment, $C f$. note 25 supra.

30. E.g., San Francisco, California; Tampa, Florida.

31. E.g., Los Angeles, California; Oakland, California.

32. E.g., San Diego, California; Richmond, Virginia.

33. Evansville, Indiana; Flint, Michigan; Knoxville, Tennessee.

34. The ordinances of Evansville, Indiana and Flint, Michigan impose as one of the penalties for curfew violation imprisonment of the violator. It would seem that this would warrant considering the ordinance criminal in nature. It is generally held that in order to satisfy the constitutional requirements of procedural due process a criminal statute must establish ascertainable standards of guilt so that men of common intelligence cannot be required to guess at the meaning of the enactment. See, e.g., Winters v. New York, 333 U.S. 507 (1948); Lanzetta v. New Jersey, 306 U.S. 451 (1939). A curfew lacking any ascertainable time of termination would not seem to satisfy these standards of definiteness.

35. Detroit, Michigan; Minneapolis, Minnesota; Cleveland, Ohio; Columbus, Ohio; Portland, Oregon (see note 37 infra) ; Salt Lake City, Utah; Seattle, Washington (see note 36 infra).

36. Phoenix, Arizona; Jacksonville, Florida; Elizabeth, New Jersey; Buffalo, New York; Seattle, Washington (see note 35 supra).

37. San Jose, California; Denver, Colorado; Chicago, Illinois; Peoria, Illinois; Wichita, Kansas; Camden, New Jersey; Portland, Oregon (see note 35 supra); Philadelphia, Pennsylvania.

38. E.g., Minneapolis, Minnesota (under 14, 9:30 p.m.; 14-18, $11: 00$ p.m.) ; Salt Lake City, Útah (under 14, 10:00 p.m.; under 18, $11: 00$ p.m.). 
difficulty of its enforcement. ${ }^{39}$ The seasonal-time variation, although making no distinction among age groups subject to the curfew, provides for a later time at which the curfew becomes effective during the summer months than during the remainder of the year. ${ }^{40}$ In addition to the fact that the sun sets at a later hour in the summer months, making it more difficult to keep children indoors, such a provision is probably motivated by the thought that during summer vacation juveniles should be treated more leniently. If, however, during free time a child is more prone to get involved in an act of delinquency, it would seem that a seasonal-time variation tends to defeat the purpose of the ordinance. A weekend-time variation likewise applies the designated time uniformly to all age groups, but extends the time limit on Friday and Saturday nights. ${ }^{41}$ The same criticism advanced with respect to the seasonal-time variation would seem to be applicable to this variation.

Information gleaned from reporting cities indicates that the provisions governing both the age groups subject to the curfew and the time at which it goes into affect are drafted on the basis of uninformed guesses rather than as a result of investigation into the incidence of criminal activity. The determination of both age and time limitations by a municipality which seeks to enact a curfew ordinance should not be an arbitrary matter. The Model Curfere Ordinance suggested by the National Institute of Municipal Law Officers leaves time and age variations to municipal discretion. ${ }^{42}$ It would seem that each city must first determine which age groups account for the major portion of juvenile delinquency and, secondiy, ascertain the hours during which nocturnal crime is the greatest. Further, the restrictions should not be so severe as to seriously curtail normal and advisable juvenile evening activities. Finally, consideration of the adequacy of available housing facilities should influence the hour at which children are required to be indoors.

\section{Juvenile Conduct Prohibited}

The most significant divergence among the ordinances lies in the conduct prohibited. On the basis of the broadest scope of conduct prohibited

39. It is difficult to distinguish on sight between two age groups of children. Further stratification of children beyond the distinction between those subject to the curfew and those not subject serves to complicate the identification process, adding much wasted motion to the task of the police. On the other hand, the distinction between age groups is essential to the operation of any curfew, and it can be maintained that if the curfew can be enforced with respect to one age division, it also can be enforced where there are several, since at any one hour in the evening there is only one age differentiation to be made.

40. E.g., Elizabeth, New Jersey (May 15 to Oct. 15, 9:30 p.m.; Oct. 15 to May 15, 9:00 p.m.) ; Jacksonville, Florida (Oct. 1 to April 1, 10:00 p.m.; April 1 to Oct. 1, 11:00 p.m.).

41. E.g., Peoria, Illinois (Sunday through Thursday, 10:00 p.m.; Friday and Saturday, 12 midnight); San Jose, California (Sunday through Thursday, 10:00 p.m.; Friday and Saturday, 12:30 a.m.).

42. National Institute of Municipal Law Officers, Model Curfew OrdiNANCE SERVICE \$\$ 7-401, 7-402 (Rhyne ed. 1952). 
by each of the examined ordinances there appear to be two basic types: the "presence" type and the "loitering" type. The "presence" type makes it unlawful for a minor "to be" in any of the restricted areas during curfew hours. ${ }^{43}$ The "loitering" type ordinance employs a more flexible restriction apparently permitting the juvenile more freedom of conduct. ${ }^{44}$ While the distinction between these two types of ordinances seems great, in practice the scope of each might be identical. The writers' experience in Philadelphia, which has the "loitering" type ordinance, reveals that the police enforce the curfew as if it were a "presence" type ordinance, giving it a broader impact than otherwise might be expected. ${ }^{45}$ On the other hand, the extent of the exceptions to the conduct proscribed by the ordinance may operate to give a "presence" type ordinance a narrower impact than first would appear. ${ }^{46}$ Three municipalities provide variations in the conduct prohibited according to the age of the child; ${ }^{47}$ the ordinance as applied to younger children prohibits "being" but when applied to older children prohibits "loitering." The rationale behind such ordinances would seem to be that a younger child generally has less reason to "be" away from home late at night. However, if the enforcement experience in these cities parallels that of Philadelphia, the statutory distinction would appear to be purely verbal.

\section{Prohibited Places}

The narrowest form of curfew ordinance is that which prohibits the child from being or loitering on the "streets" 48 after the curfew hour. At the other extreme are those ordinances which extend to "public streets, highways, roads, alleys, parks, playgrounds, or other public grounds, places of amusement and entertainment, vacant lots or other unsupervised

43. "Presence" type ordinances take various forms. The following are typical: "unlawful ... to be" (Camden, New Jersey; Akron, Ohio); "unlawful . . . to be or remain" (Flint, Michigan; Knoxville, Tennessee); "unlawful . . . to walk, loiter, idle, wander, stroll or play or be present" (Omaha, Nebraska; Milwaukee, Wisconsin).

44. "Loitering" type ordinances take various forms. The following are typical: "unlawful . . . to loiter" (Pasadena, California); "unlawful . . . to loiter or remain" (Richmond, Virginia); "unlawful ... to remain" (Philadelphia, Pennsylvania: the ordinance defines "remain" as "to loiter, idle, wander, stroll or play"); "unlawful ... to loiter, idle, wander, stroll or play" (Columbus, Ohio); "unlawful ... to be and remain" (Norfolk, Virginia).

45. See text at notes 110-12 infra.

46. See text and notes at notes 58-64 infra. Cf. Michigan Munictpal League, Curfew Ordinances 1 (1950): "The Model Curfew Ordinance of the National Institute of Municipal Law Officers could be called a 'loitering' type of ordinance but it is so worded as to actually become a "presence' type with the exemptions included"

47. Detroit, Michigan (under 12 "to be"; under 17 "to loiter"); Minneapolis, Minnesota (under 14 "to be"; under 18 "to loiter"); Seattle, Washington (under 16 "to be"; under 21 "to loiter"). Buffalo, New York employs the novel provision that "no . . child ... shall be allowed to loiter, peddle, or be engaged in any avocation."

48. E.g., San Francisco, California; Buffalo, New York. Cf. Akron, Ohio and Cleveland, Obio which apply to "streets and sidewalks." 
places." 49 Between these extremes in language other forms appear, such as "streets and other public places" 50 or "any street, road, avenue, alley, park or other public places." ฮ1 Many cities extend curfew coverage to "places of amusement and entertainment" on the theory that as much harm may subsequently result from juveniles "hanging-out" in habitual places of congregation ${ }^{52}$ as will result from their being or loitering outdoors. ${ }^{53}$

It would seem, however, that the above distinctions once again are more verbal than actual. The large majority of the examined ordinances, after enumerating a specific prohibited location or locations, employ the general term "other public places." 54 Since few of the ordinances define this term ${ }^{55}$ it is probable that police with rigorous enforcement policies interpret the term as applying to any place, whether enclosed or not, to which the public is admitted. ${ }^{56}$ Such an interpretation would render the distinction between the ordinances without effect. ${ }^{57}$

49. E.g., St. Paul, Minnesota; Columbus, Ohio. Many variations of this form appear, either adding or deleting terms. The Model Curfew Ordinance of the National Institute of Municipal Law Officers also follows this form. The ordinances of Peoria, Illinois and Philadelphia, Pennsylvania apply to "any public place or establishment." These terms are defined in both as follows: Public place is "any public street, highway, road, alley, park, playground, wharf, dock, public building or vacant lot." Establishment is "any privately owned place of business carried on for a profit or any place of amusement to which the public is invited."

50. E.g., Tampa, Florida; Knoxville, Tennessee.

51. E.g., Richmond, Virginia. Many variations of this form appear, either adding or deleting terms.

52. See text and notes at notes 87-90 infra.

53. Under the ordinances which apply primarily to places in the open, the police are handicapped in not being able to apprehend children found in drugstores, eating places, bowling alleys, and the like. It then becomes a battle of wits as to whether the child can get home without being caught.

54. See text and notes at notes 50-51 supra.

55. Cf. Philadelphia, Pennsylvania curfew ordinance which contains an excellent section on definition of terms used in the ordinance. Philadecphia, Pennsylvania, COde of Gen. Ordinances $\$ 10-302$ (1956). See note 49 supra.

56. The confusion arising from the use of the term "public place" would seem to be particularly acute in those municipalities with ordinances pertaining to "streets and other public places." See note 50 supra. An examination of judicial interpretations of the term "public place" does not help to clarify the situation. It has been applied to include a poolroom, Griffin v. State, $15 \mathrm{Ga}$ App. 552, 83 S.E. 871 (1914); a cafe, Francis v. Town of Falkville, 24 Ala. App. 478, 136 So. 866 (1931); and a hotel, State v. Musser, 67 Idaho 214, 176 P.2d 199 (1946). On the other hand, it has been held not to apply to a saloon, State v. Colgan, 92 N.J.L. 307, 108 At1. 108 (Sup. Ct. 1919); and a store, State v. Bruns, 134 N.J.L. 393, 48 A.2d 577 (Sup. Ct. 1946). In Madison Prod. Co. v. Coler, 242 N.Y. 467, 152 N.E. 264 (1926), it -was held that a statute which prohibited solicitations in "streets and public places" did not authorize interference with soliciting in houses, offices and factories. The problem of interpretation may not be so severe in those municipalities which have ordinances of the type which apply to "any street, road, avenue, alley, park, or other public place." In such cases the statutory rule of construction of ejusdem generis might more easily be applied: "Where general words follow specific words, in an enumeration ... the general words are construed to embrace only objects similar in nature to those enumerated by the preceding specific words." 2 SUTHERLAND, Statutory Construction $\$ 4909$ (3d ed. Horrack 1943). By applying the rule to the ordinance in question the ordinance would not seem to apply to enclosed places. $C f$. Norfolk, Virginia curfew ordinance which after naming ten specific places says "any other public place, whether of like kind or not."

57. In some ordinances a distinction in the nature of the conduct prohibited is made on the basis of the places to which the curfew extends. For example, Fresno, 


\section{Conduct Excepted From the Curfew}

All of the ordinances examined contained provisions excepting certain conduct from the operation of the curfew. ${ }^{58}$ Some of the more common exceptions are: 1) a minor accompanied by his parent, or guardian or cther adult person having the legal care, custody or control of such minor; ${ }^{69}$ 2) a minor engaged in lawful employment; ${ }^{60} 3$ ) a minor on an emergency errand or on legitimate business directed by his parents, guardian or other adult person having the legal care, custody or control of such minor; ${ }^{61}$ 4) a minor returning home from school or church-sponsored activities when such minor's presence was authorized by his or her parent, guardian, or other adult person having the legal care, custody or control of such minor. ${ }^{62}$ Many additional exceptions can be found which are not common to the majority of the ordinances. 63 In Cleveland, Ohio and Detroit, Michigan the number of exceptions varies according to the age of the child involved-the older the child the more exceptions that are available, apparently on the legislative assumption that there are more legitimate reasons for an older child to be out than exist for a younger child.

The large number of exceptions prevalent in curfew ordinances can be accounted for in several ways. First is the draftsman's desire to satisfy the constitutional requirements of due process, since it has been held that curfew ordinances without reasonable exceptions are so great a restraint

California prohibits "loitering" upon the streets and "being" in places of amusement or entertainment. See also the Seattle, Washington ordinance which prohibits a person under 21 from loitering in "any public dance hall, public pool or billiard room or hall or drinking resort" and a child under 16 "to be abroad in or upon any public place."

58. Cf. Cleveland, Ohio curfew ordinance which has no exceptions for children under 12 years of age. Exceptions are provided for children between the ages of 12 and 16.

59. A similar provision appeared in every one of the examined ordinances. Many municipalities provide further that the child may be accompanied by "any adult person having the permission from the parent or guardian" (e.g., Akron, Ohio), or "spouse of such person over twenty-one" (e.g., Long Beach, California), or "is otherwise properly chaperoned by some adult person" (e.g., Nashville, Tennessee).

60. This is a provision which appeared in virtually all of the examined ordinances. Detroit, Michigan, while having the general exception, prohibits certain specific types of employment during curfew hours.

61. Although most ordinances contain this exception, few provide means by which evidence of such permission is obtained (e.g., Columbus, Ohio). Norfolk, Virginia requires the child to carry a written statement to that effect. Apparently many smaller municipalities do not require permission for emergency errands. See Michigan Munictpal League, Curfew Ordinances 4 (1950).

62. E.g., Indianapolis, Indiana. While not requiring permission, Sacramento, California provides an exception if the "minor is returning directly home from a meeting, entertainment, recreational activity or dance."

63. E.g., "Where a regular program or evening's entertainment shall have commenced . . at $8: 30$, or prior thereto, and shall have been held over [beyond curfew], or such person shall have left a : . social call after [curfew] and such person is thereafter returning directly to his home . . not later than 12 o'clock midnight." (Fresno, California). If the minor is "attending to some urgent business and can give a satisfactory reason for being away from home" (Phoenix, Arizona). If "there exists a reasonable necessity" for being out beyond curfew (Minneapolis, Minnesota). Many small municipalities provide exceptions for prom nights, special school events and the like. E.g., Albert Lea, Minnesota; Williams, Minnesota. 
on individual freedom as to be unconstitutional. ${ }^{64}$ Second, certain exceptions are not inconsistent with the general aims of a curfew ordinance, e.g., little harm is likely to result if the minor is in the company of his parent, his guardian or a person having legal custody. Third, many of the exceptions are probably the result of legislative desire to strike a "fair" balance between effective crime control and freedom of movement, and also to encourage certain conduct on the part of the youth. The latter would seem particularly true of the employment, emergency errand and church and school activity exceptions.

\section{Penalties for Curfew Violation}

Several of the examined ordinances contain no specific provision for sanctions against the child who is in one of the proscribed places after the curfew hour, ${ }^{65}$ preferring to rely upon sanctions against other persons made responsible for the conduct of the child to enforce the ordinance. ${ }^{66}$ These ordinances, nevertheless, do make certain conduct by the child "unlawful," 87 and in many instances it is probable that the cities have general fine and penalty ordinances applicable to ordinances in which a specific penalty is not provided.68 Many of the remaining ordinances contain specific penalty provisions, but a marked divergence in the maximum sanctions authorized is evident among them. Some permit only fines ${ }^{69}$ while others allow fines and imprisonment, ${ }^{70}$ the least severe maximum fine being ten dollars ${ }^{71}$ and the most stringent maximum penalty being $\$ 500$ fine and six months' imprisonment. ${ }^{22}$ Coupled with the imposition of a fine and imprisonment, several cities term violations of the ordinance a misdemeanor. ${ }^{73}$ The final type of ordinance provides that the violating child may be treated under the state juvenile court statute governing delinquents. ${ }^{74}$

64. See text and notes at notes 188-91 infra.

65. Philadelphia, Pennsylvania; Seattle, Washington.

66. For a discussion of parental responsibility generally see LudwIG, YoutH AND THE LAW 131-67 (1955). See text and notes at notes 76-86 infra.

67. E.g., Denver, Colorado.

68. See, e.g., Phinadelphia, Pennsylvania, Code of Gen. Ordinances \$1-109 (1956). The curfew ordinance of Cleveland, Ohio specifically refers to such a general penalty ordinance.

69. Wichita, Kansas; Philadelphia, Pennsylvania; Richmond, Virginia.

70. Columbus, Ohio; Dayton, Ohio; St. Paul, Minnesota.

71. Jacksonville, Florida.

72. Berkeley, California. Arizona.

73. Corpus Christi, Texas; Omaha, Nebraska; Pasadena, California; Phoenix,

74. Indianapolis, Indiana; St. Paul, Minnesota; Wichita, Kansas. In addition to providing a general penalty, Flint, Michigan states that "if after investigation. . . it is found that the child is incorrigible or wilfully absents himself or herself from home and that the parents are unable to control such child, then a complaint in that case shall be made by the proper authorities under the juvenile law of the state." Richmond, Virginia has elaborate provisions for the investigation of each case. 
In those municipalities that impose no sanction on the child violator, reliance is placed on the sanctions against parents, who are made legally responsible. Undoubtedly, the threat of fine or imprisonment in many instances has the effect of inducing lax parents to control the activities of their children. In addition, many so-called "good" children will respond on their own initiative to obey the curfew in order to prevent the embarrassment of a public hearing and penalty from being inflicted on their parents. However, there are children who persist in staying away from home at night despite parental orders to the contrary. These are the children who are most likely to engage in the criminal activity that the curfew seeks to prevent, but against such children a sanction on the parents is particularly ineffectual. However, granting that some direct remedy is desirable, the appropriate choice is not obvious. Imposition of a monetary fine on children lacks merit. Since most of the children subject to the curfew attend school, they are either unable to pay the fine or would acquire money to pay the fine from parents or through some act of delinquency. Moreover, the mandatory charging of a misdemeanor would not seem desirable. A curfew violation alone should not merit burdening a youth with a criminal record for life, since a curfew violation is not itself indicative of conduct inherently dangerous to society. Perhaps the best of the available sanctions would be treatment as a juvenile delinquent, which involves discretionary handling of the juvenile's case by an appropriate state authority designed to cope with juvenile delinquency. ${ }^{75}$

\section{Parental Responsibility}

All but one ${ }^{76}$ of the curfew ordinances examined proscribed certain conduct on the part of parents or guardians, with penalties imposed for violation. ${ }^{77}$ The purpose of these provisions is to make parents the primary agents of curfew enforcement. The most prevalent type of ordinance is that which makes it unlawful for a parent or guardian to "permit" or to "permit or allow" a child to violate the curfew provisions. The word "permit" is imprecise, having been defined in other contexts as express assent to the doing of an act or acquiescence by failure to prevent the doing of an act. ${ }^{78}$ Hence, the ordinances do not reveal whether a parent's lack of knowledge of the child's violation constitutes a defense. Other municipalities are more explicit. Portland, Oregon states that the parent shall not "permit or by inefficient control allow," while Phoenix, Arizona invokes a broad meaning to "permit" by providing that "it shall not constitute a

75. For a complete discussion of juvenile delinquency and its treatment, including the functions of a Juvenile Court, see THE JUVENILE OFFENDER (Vedder ed. 1954).

76. San Jose, California does not provide for parental responsibility.

77. For discussion of parental responsibility see generally LUDWIG, YouTH AND THE I AW 131-67 (1955); Gladstone, The Legal Respoissibility of Parents, 21 BRookIYN L. REV. 172 (1955); Note, Parental Responsibility for Juvenile Delinquency, 34 Cer.-KENT L. Rev. 222 (1956).

78. Tenney v. Enkeball, 62 Ariz. 416, 158 P.2d 519 (1945); Hodges v. Ocean Acc. \& Guarantee Corp., 66 Ga. App. 431, 18 S.E.2d 28 (1941); A. E. Holly \& Co. v. Simmons, 38 Tex. Civ. App. 124, 85 S.W. 325 (Civ. App. 1905). 
defense that such parent or guardian did not have knowledge." 79 A second type ordinance is that which provides that the parent shall not "knowingly" permit a violation on the part of the child. ${ }^{80}$ This language appears to remove the doubt in meaning on the issue of knowledge inherent in the preceding type ordinance. However, Philadelphia, Pennsylvania has interpreted "knowingly permit" as an objective test, meaning the knowledge which a parent should reasonably be expected to have concerning the whereabouts of his children. ${ }^{81}$ Such a construction materially diminishes the effect of the knowledge requirement, but it nonetheless appears to be more consonant with the purposes of imposing parental responsibility. If the objective of such a provision is to encourage parental control over the nighttime activities of children, an ordinance which prohibits only knowing conduct does not encompass the neglectful or careless parent, since the parent always would have the defense that he or she "didn't know" that the child was not at home, bounded only by the limits of credulity.

Penalties imposed upon parents for violation of the ordinance are similar to those imposed upon children. Some municipalities declare the parental conduct unlawful and then apply a general penalty ordinance. ${ }^{82}$ Others specifically provide for penalties ranging up to $\$ 500$ fines and/or maximums of six months' imprisonment. ${ }^{83}$ Many of the cities which provide for specific penalties have a graduated scale of fines dependent upon the number of violations. ${ }^{84}$ In addition, several ordinances provide that a parent's violation is a misdemeanor. ${ }^{85}$ In this area, as well as that concerning penalties imposed upon children, the question should be raised whether the aims of a curfew could be accomplished with less severe penalties. ${ }^{86}$

\section{Responsibility of Third Persons}

The geographical scope of many curfew ordinances extends to places of amusement and entertainment. ${ }^{87}$ To facilitate enforcement of these

79. Cf. San Francisco, California, which provides that, "Upon violation by a juvenile . . . a rebuttable presumption arises that the parent or guardian assisted, aided, abetted and encouraged such minor to violate. . ." Detroit, Michigan has a similar ordinance.

80. Corpus Christi, Texas; Dayton, Ohio.

81. Interview with Raymond Kitty, Assistant City Solicitor, Philadelphia, Pennsylvania, Aug. 22, 1957.

82. Camden, New Jersey; Fresno, California.

83. Berkeley, California; Gary, Indiana. Cf. Buffalo, New York which imposes a monetary penalty upon the child but makes the parent liable in an action to recover the penalty owing from the offending child.

84. Philadelphia, Pennsylvania gives the parent a warning on the first violation and on any violations thereafter provides for fines of $\$ 5.00$ to $\$ 100.00$, with imprisonment for a maximum of ten days if the fine is not paid promptly. Akron, Ohio provides for fines of $\$ 5.00$ to $\$ 25.00$ for the first violation and fines of $\$ 10.00$ to $\$ 49.00$ for every violation thereafter.

85. Duluth, Minnesota; Dayton, Ohio.

86. See text at notes $65-75$ supra.

87. See text at notes 49-53 supra. 
provisions five cities ${ }^{88}$ place an obligation upon the individual, firm or corporation operating such an establishment to prevent any minor from remaining on the premises during the hours of curfew. ${ }^{89}$ Violating these provisions results in fines and/or imprisonment.90 Absent such a provision a proprietor might harbor the juvenile and encourage violations, not being concerned with whether the juvenile is acting unlawfully so long as he is spending money in the establishment. A provision which places a penalty upon proprietors should operate as an inducement to aid the parents and police to enforce the curfew, easing the police task of enforcement and encouraging the juveniles who realize that they will not be permitted to "hang out" in places of amusement or entertainment during curfew hours to stay at home.

\section{State Curfew Legislation}

Oregon is the only state that has specifically enacted a curfew statute. ${ }^{21}$ This statute follows the general form of the municipal ordinances previously discussed. It provides that a child under eighteen years of age shall not be in or upon the streets, highways, parks, alleys or other public places between the hours of 12 midnight and 4:00 a.m. It also prohibits a parent from allowing a violation. On the first violation the child is taken to juvenile court and is subject to fine or imprisonment, or both. A violation by a parent is a misdemeanor. The statute further provides that municipalities also may enact ordinances so long as the effective hours are at least as restrictive as those in the state statute. ${ }^{92}$

Eleven other states have statutes containing provisions which, if enforced, would have the effect of curfews. ${ }^{93}$ These statutes, in defining juvenile delinquency, include any child who wanders about the streets

88. Peoria, Illinois; Minneapolis, Minnesota; Philadelphia, Pennsylvania; Richmond, Virginia; Milwaukee, Wisconsin.

89. Richmond, Virginia places responsibility upon the proprietor, provided there is conspicuously posted at the entrance of such place of amusement or entertainment a notice containing the curfew provisions. The efficacy of this proviso is questionable. It would seem that responsibility may be avoided simply by failing to post a notice, since there is no provision requiring posting.

90. Cf. the ordinance of Detroit, Michigan which provides that "any person assisting, aiding, abetting, or encouraging" a minor to violate the curfew shall be guilty of a violation. This would seem to have a broader scope than the ordinances cited in the text, and would have the same advantages. However, from another standpoint, the clause is unfortunate in that it is unclear as to what constitutes assisting, aiding, abetting or encouraging.

91. ORE. Rev. Stat. $\$ \S 419.710,419.720,419.730,419.740,419.990$ (1953). A curfew statute was introduced in the Arizona State legislature in 1955. F. L. Manella, Report on CuRfew Law 9 (Fla. Children's Comm'n 1956). Apparently it has not yet been enacted.

92. The ordinance of Portland, Oregon extends from 9:15 p.m. to 6:00 a.m. and hence is valid under the statute.

93. ARk. Stat. Ann. § 45-204 (1947) ; Conn. Gen. Stat. \$2802 (1949); Idaho Code ANN. \$ 16-1803 (Supp. 1957) ; Ill. ANN. Stat. c. 23, § 2001 (1958); IND. ANN. Stat. \$ 9-3204(11) (1956); N.J. Stat. AnN. \&2A :4-14(k) (1957); ÓkLA. Stat. ANN. tit. 10, 101 (1951); S.D. CoDE $\$ 43.0301$ (1939); TENN. CODE ANN. $\$ 37-242$ (1955); VT. REv. Stat. \$9884 (1947); WasH. Rev. Code \$13.04.010(17) (1956). 
in the nighttime without being on any lawful business or occupation. ${ }^{94}$ However, such provisions are of doubtful constitutional validity since they may be so vague as to deny due process to those persons subject to them..$^{95}$ Even if the statutes survive this constitutional impasse, they are subject to the further policy objection that no provision is made for parental responsibility. Furthermore, state curfew laws are of questionable efficacy since the enforcement pattern may reflect the fact that they do not take into account local factors such as public reaction and the need for the measure. ${ }^{96}$ Of the reporting cities in those states having such statutes, only Fort Wayne, Indiana stated that the statute is enforced as a curfew by the local authorities. However, it is noteworthy that Indianapolis, Indiana found the same statute inadequate and enacted a supplementary ordinance. ${ }^{97}$

\section{Curfew Ordinance in Operation in Philadelphia}

As part of the study of the practical application of curfew ordinances, observations were made in Philadelphia of the police enforcement, the prosecutions, and the minor judiciary's dispositions of cases under its ordinance. The information upon which the following discussion is based was obtained to a large degree from interviews with officials and members of the Philadelphia Police Department, from their records and from personal observation..$^{98}$

To properly analyze the administration of the curfew, it must be examined against the background of the local procedure established to administer juvenile criminal matters generally. Philadelphia's juvenile criminal procedures, encompassing the activities of those under eighteen years of age, are segregated from its adult criminal procedures. ${ }^{99}$ A special division of the police force, the Juvenile Aid Bureau, is charged with the responsibility of enforcing criminal laws against juveniles, including the detection and apprehension of violators. While any regular police officer can detain and hold a juvenile, only a member of the Juvenile Aid Bureau

94. Houston, Texas enforces as a curfew a statute which states "[A]ny peace officer or probation officer shall have the right to take into custody any child who is . . . reasonably believed to be a fugitive from his parents or from justice, or whose surroundings are such as to endanger his health, welfare or morals." TEx. Rev. Civ. Stat. AnN. art. 2338-1, § 11 (1950).

95. See note 34 supra.

96. American Munictpal Assoctatton, Informatton Memorandum No. 48-2CuRFEw ORdinances (March 19, 1948). "[I]n no event should [a curfew] be enacted unless considerable sentiment in favor is found to exist among . . . the community. ..."

97. The Indiana juvenile court had construed the state statute prohibiting "wandering" by a juvenile as not including being in an automobile. The Indianapolis curfew specifically covers "being in" vehicles.

98. Because of the confidential nature of many of these sources, in most cases it has been necessary to omit the names of the persons involved.

99. Pa. Stat. Ann. tit. 17, §694(b) (1930); PA. Stat. Ann. tit. 11, §244 (Supp. 1957). For an excellent statement of Philadelphia procedures for dealing with juvenile crime see Municipal Court of Philadelphia, Report 13-15 (1954). 
can make what is termed in Philadelphia police statistics as an "arrest." 100 A juvenile held by a regular police officer is turned over to a Juvenile Aid Bureau officer who determines whether the detained juvenile should be "arrested." If not, the juvenile is released and a "non-arrest" is recorded by the officer. ${ }^{101}$ If, however, the juvenile is arrested he is put into the custody of the Youth Study Center. ${ }^{102}$ Within one day an informal hearing is held, the legal function of which roughly approximates that performed by a magistrate's court with regard to adult criminal matters, i.e., the determination of whether there are reasonable grounds for believing that the juvenile committed the act for which he was arrested. Arrests for minor delinquencies may be adjusted at the informal hearing. If the charge is more severe, requiring further investigation and judicial disposition at a formal hearing, the case is listed for the juvenile division of the municipal court.103 However, in cases of murder and other heinous crimes the case trial is in the county criminal court.104 The municipal court, in addition to having jurisdiction over proceedings affecting delinquent children, retains jurisdiction over adults charged with acting in violation of state and local laws with respect to children. ${ }^{105}$

\section{A. Patterns of Police Enforcement}

In contrast with the procedure for handling instances of juvenile delinquency, the curfew ordinance is enforced in much the same manner as are municipal traffic laws. The Philadelphia curfew ordinance makes it unlawful for a child under seventeen to remain in certain designated places after the curfew hour, ${ }^{106}$ but no sanction is specified in the ordinance against the child. ${ }^{107}$ Sanctions are prescribed for parents who knowingly permit their children to violate the ordinance after having received notice of a prior violation by the child. ${ }^{108}$ Under this ordinance primary responsibility for detection and enforcement falls on the regular police force, since the staff of the Juvenile Aid Bureau is inadequate to perform the

100. See text at notes $110-12$ infra.

101. The Juvenile Aid Bureau officers have broad discretion in determining whether the juvenile's detention shall be recorded as an "arrest" or "non-arrest." To the extent that this discretion is not uniformly exercised juvenile criminal statistics are inaccurate criteria of the incidence of juvenile criminal activity. See text and notes at notes $173-78$ infra.

102. The Youth Study Center of the juvenile division of the municipal court is an institution for the reception of juveniles whose cases are under judicial investigation. Pa. Stat. AnN. tit. 11, § 441 (Supp. 1957).

103. Pa. Stat. Anv. tit. 17, $\$ 694$ (b) (1930) ; Pa. Stat. Ann. tit. 11, $\$ 244$ (Supp. 1957).

104. PA. Stat. Ann. tit. 17, §694 (1930).

105. Pa. Stat. Ann. tit. 11, \$244 (Supp. 1957).

106. Philadetphia, Pennsylvania, Code of Gen. Ordinances $\$ 10-303$ (1956).

107. Id. $\$ 10-306(1)$.

108. Id. \$\$ 10-304, 10-306(2). 
task. ${ }^{109}$ Notice of a violation is sent to the parent. Upon a second violation, a summons is served on the parent and a hearing is held in the magistrate's court, at which time the parents' penalty under the ordinance may be imposed.

\section{Detection of Violations}

If a police officer sees a person who appears to be under-age, the policeman generally stops the juvenile and questions him. The ordinance provides that at this juncture the officer is to obtain the name, age and address of the child as well as the name of the parent or parents, and then to instruct the juvenile to proceed to his home. ${ }^{110}$ Although the prescribed procedure is followed in many instances, other variant procedures have been employed by the contacting officers. On many occasions the police officer will merely direct the child to go home without recording any of the information called for by the ordinance, thus frustrating the attempt of the curfew law to impose responsibility on the parents for the conduct of their children. On other occasions the contacting police officer will record the required information and then personally escort the child to his home. ${ }^{111}$ A third variation, of questionable propriety, is that of picking up the child and taking him to the station-house, to be released only when the parent personally appears. According to the police, aside from instances of lost or runaway children, this procedure is employed either when the contacting officer believes that the child is giving misinformation in response to the officer's inquiries, or when the contact is made as a result of a complaint to the police department, or when the juvenile is contacted on suspicion of having been involved in some criminal act. In the latter two situations the Juvenile Aid Bureau officer in the district is notified and assumes jurisdiction. He then directs that an "arrest" or "non-arrest" be recorded, depending upon the likelihood of the child's having committed an act of delinquency. In no event is an "arrest" recorded where the child's sole infraction is curfew violation. In the first situation, where the child is suspected of giving misinformation to the contacting officer, the Juvenile Aid Bureau officer is notified only if further questioning indicates that the activity in which the child was engaged at the time of the contact was such as might require further investigation or detention. Otherwise, the child is released to his parents upon their arrival at the police station with no recordation of an "arrest" by the

109. At the end of 1957 there were 210 employees in the Juvenile Aid Bureau, a force scarcely large enough on a three shift basis to effectively police a city with more than 300,000 juveniles between the ages of seven and seventeen. Interview with Inspector Harry J. Fox, July 30, 1957. Currently, fifty more police officers have been added to the Juvenile Aid Bureau, bringing its total force to 260 .

110. Philadelphra, Pennsxlvania, Code of Gen. Ordinances \$10-306 (1956).

111. It is not unlikely that children substantially below the curfew age limit who are away from home late in the evening are either lost or running away from home, in which case the police, apart from curfew enforcement, should take the child into protective custody and attempt to locate his parents. 
police department. Detention by the police is an arrest, ${ }^{112}$ regardless of the terminology employed by them in reporting case disposition. In general, under the common law an arrest could legally be made without a warrant whenever the arresting officer has reasonable grounds to believe that the person to be apprehended has committed a crime. ${ }^{113}$ Detention of children contacted by the police can be justified, apart from the curfew law, under the general law by the theory that the arresting officer had reason to believe that the juvenile had committed an act of delinquency. ${ }^{114}$ However, where the detention is effected solely because the contacting officer suspects that the child is giving misinformation in response to his inquiries, i.e., where no act of delinquency is charged, legal justification appears to be wanting. Misinforming the police is not a crime in itself. Since no sanction is provided against the curfew violator in that ordinance, arrest for curfew violation would seem purposeless and not provide legal justification for the detention. ${ }^{115}$ Although the language of the statute defining "juvenile delinquency" is sufficiently broad to include a curfew violation, no case has yet so held, nor do the police appear to consider curfew violation an act of delinquency under the ordinance. On the other hand, if strict legality were to be honored, brash children could make effective enforcement of the curfew impossible. Children under seventeen rarely carry identification on their persons. Unless the police should personally escort every offender to his home, which would be an intolerable burden on the force, the parents would remain unknown, leaving the curfew a law without a sanction.

\section{Extent of the Enforcement}

Enforcement of the Philadelphia curfew ordinance began on February 1, 1955.116 Since that date the number of reported curfew violations on

112. 1 Alexander, The LAW of ARrest 353-61 (1949). See Foote, Safeguards in the Law of Arrest, 52 Nw. U.L. Rev. 16, 36-44 (1957) ; Note, 100 U. PA. L. Rev. $1182,1185-88$ (1952).

113. See 1 Alexander, op. cit. supra note 112, at 364-68, 441, 451-57.

114. There may be serious question as to whether an arrest without a warrant for an act of delinquency, being neither felony nor misdemeanor, is valid under these circumstances. For the purposes of analyzing the legality of such an arrest under the curfew ordinance alone, however, this problem need not be decided.

The statute defines a delinquent child as "(a) A child who has violated any law of the Commonwealth or ordinance of any city, borough or township; (b) A child who, by reason of being wayward or habitually disobedient, is uncontrolled by his or her parent, guardian, or custodian or legal representative; (c) A child who is habitually truant from school or home; (d) A child who habitually so deports himself or herself as to endanger the morals or health of himself, herself or others." PA. STAT. ANN. tit. 11, \$\$243(4) (a)-(d) (1939).

115. Pailadelphia, Pennsylvania, Code of Gen. Ordinances \$10-306(1) (1956). But see PA. Śtat. ANN. tit. 53, §13349 (1957), authorizing “[A]ny police officer. . . upon view of the breach of any ordinance of any city of the first class - - to forthwith arrest the person or persons so offending, without any process .. " and to take the offending person to a magistrate to fix a time for a hearing. Ibid. But under the curfew, there can be no hearing, as there is no sanction against an offending juvenile. See text and note at note 107 supra.

116. Interview with Inspector Harry J. Fox, July 1, 1957. 
the part of juveniles has been increasing steadily. In the eleven months of $1955,2,051$ violations were reported; during the twelve months of $1956,2,990$ violations were reported; 1957 witnessed 6,973 curfew violations. ${ }^{117}$ On the basis of the average number of violations per month during each of the three years of its enforcement the figures reveal that in 1955 there were 186.5 violations per month, in 1956 there were 249.2 violations per month (an increase of 33.6 per cent over 1955) and in 1957 there were 581.1 violations per month (an increase of 133.2 per cent over 1956 and 210.9 per cent over 1955).

Despite the over-all increase in the incidence of curfew violations, attributable to an accelerated effort on the part of the districts to enforce the curfew, examination of statistics of reported violations by police district reveals a singularly irregular pattern of enforcement. Comparison by district on the basis of the number of violations occurring within each district per thousand juveniles aged seven to seventeen residing within the district ${ }^{118}$ reveals that those districts with the heaviest rate of juvenile crime, as

117. Unless otherwise specified all curfew, arrest and non-arrest statistics, except those reported in the section on judicial administration, were taken from the records of the Juvenile Aid Bureau.

118. Source of the juvenile population statistics is the Crmme Preventron AssoCiation of Philladelphia, Report (1955). The Crime Prevention Association based its determination on estimates taken from the 1950 census.

Police Contacts (by District of Contact) Per Thousand Juventles, Ages 7-17, Residing Within the District

\begin{tabular}{crrrrrrrrr} 
& \multicolumn{3}{c}{ Non-Arrest } & \multicolumn{3}{c}{ Arrest } & \multicolumn{3}{c}{ Curfew } \\
District & 1955 & 1956 & 1957 & 1955 & 1956 & 1957 & 1955 & 1956 & 1957 \\
5 & 32.8 & 35.9 & 31.0 & 15.8 & 13.5 & 12.1 & 14.7 & 20.2 & 20.2 \\
6 & 75.7 & 62.8 & 68.9 & 103.3 & 122.8 & 101.4 & 10.7 & 15.7 & 29.6 \\
9 & 115.7 & 91.0 & 71.9 & 65.9 & 102.3 & 102.8 & 15.8 & 17.6 & 24.4 \\
14 & 37.1 & 33.6 & 31.5 & 19.0 & 24.1 & 19.8 & 4.1 & 6.3 & 18.0 \\
16 & 79.0 & 62.0 & 60.2 & 63.8 & 54.9 & 54.8 & 17.9 & 18.2 & 40.9 \\
17 & 44.0 & 49.4 & 54.1 & 33.2 & 49.9 & 37.3 & 5.6 & 7.2 & 55.2 \\
19 & 100.4 & 88.3 & 92.6 & 75.8 & 114.5 & 166.1 & 28.2 & 29.9 & 41.4 \\
23 & 82.2 & 71.5 & 54.0 & 56.4 & 65.7 & 59.4 & 9.3 & 10.4 & 9.8 \\
24 & 36.9 & 34.3 & 29.6 & 13.6 & 13.8 & 17.3 & 9.8 & 11.6 & 16.5 \\
26 & 47.4 & 38.0 & 50.4 & 25.5 & 28.0 & 35.4 & 5.2 & 3.6 & 9.5 \\
29 & 31.1 & 30.9 & 27.7 & 17.4 & 21.7 & 15.3 & 2.4 & 3.0 & 15.2 \\
30 & 39.3 & 33.1 & 40.9 & 16.8 & 26.8 & 25.0 & 4.5 & 6.0 & 18.4 \\
31 & 66.6 & 62.4 & 47.5 & 37.5 & 61.9 & 45.6 & 7.3 & 10.8 & 31.5 \\
32 & 28.4 & 32.3 & 36.7 & 14.0 & 16.2 & 17.1 & 2.9 & 3.9 & 14.7 \\
33 & 41.6 & 37.8 & 35.5 & 20.8 & 34.9 & 27.8 & 6.4 & 11.3 & 27.8 \\
35 & 26.8 & 44.2 & 24.3 & 7.5 & 9.0 & 7.2 & 10.6 & 32.6 & 38.3 \\
37 & 43.5 & 39.3 & 36.0 & 17.4 & 22.0 & 19.5 & 4.5 & 5.5 & 32.9 \\
38 & 41.2 & 40.1 & 48.9 & 22.1 & 29.5 & 35.3 & 5.6 & 4.7 & 24.0 \\
39 & 49.7 & 48.0 & 46.3 & 29.2 & 52.9 & 33.0 & 6.0 & 6.4 & 10.9 \\
41 & 43.6 & 34.0 & 28.7 & 25.2 & 29.1 & 20.4 & 5.8 & 6.1 & 10.7 \\
71 & 26.4 & 31.1 & 24.8 & 15.7 & 15.2 & 12.7 & 5.3 & 8.0 & 22.2 \\
(27) & 26.5 & 44.3 & 41.0 & 27.1 & 34.9 & 30.7 & 7.0 & 10.2 & 23.7
\end{tabular}

* Due to changes within the three year period in the geographical boundaries of three of the police districts and the termination of the 27th district and the establishment of the 7th district within this period, the figures for these districts have been combined. All the affected districts lie in the same section of the city.

The eight districts in which substantial effort to enforce the curfew was noted in 1955 were chosen on the basis of a curfew rate of nine, a number chosen for its convenience rather than its independent significance. On this basis substantial enforcement was noted in the 5 th, 6th, 9th, 16th, 23d, 24th and 35th districts. 
measured by the incidence of the juvenile arrests, tended in 1957 to have higher curfew violation rates. ${ }^{119}$ This generalization indicates that these areas may have a greater proportion of juveniles on the streets after the curfew hour than do areas with less juvenile criminal activity. Yet in a few districts where the arrest rate is significantly higher than average, the curfew violation rate is considerably lower than average, ${ }^{120}$ and in a few districts where the arrest rate is markedly lower than average, the curfew violation rate exceeds the average. ${ }^{121}$ Some variation may be attributable to the fact that there are more restaurants, places of amusement and other gathering places in certain districts with high curfew violation rates than exist in other districts. Variation may also be due, in part, to improper distribution of police personnel among the districts. The conclusion, however, is suggested that the extent of curfew enforcement is in large part determined by the attitude of the district captains and their subordinates toward the utility of the curfew as an effective crime combatant.

\section{Enforcement Against Groups of Juveniles}

Of primary concern to the Philadelphia police department in its efforts to curb juvenile crime is the prevention of the accumulations of juveniles in groups where the likelihood of illegal activity is thought to be greater than among persons acting individually. ${ }^{122}$ As a consequence, patrolling police officers often do not bother to stop individuals after the curfew hour who, although apparently in the age group subject to the curfew, are alone and appear to be headed for a destination as opposed to lounging on a street corner. On the other hand, whenever a group of more than two juveniles is spotted, the police almost invariably stop the children regardless of whether the group appears to be headed for a destination. ${ }^{123}$ In order to prevent group accumulations, the police periodically check places of habitual congregation, and upon finding a group of juveniles, use their authority under the curfew ordinance to disperse them. Whether the police consider that the curfew has given them new authority in this regard is questionable. Even before its enactment the police did not hesitate to act whenever a group of juveniles or adults became boisterous on the streets or congregated in large numbers about any eating place or like

119. E.g., the 6th, 9th, 16th, 17th, 19th and 31st districts. See note 118 supra.

120. The $23 \mathrm{~d}$ and 26 th districts. See note 118 supra.

121. The 35th and 37th districts. See note 118 supra.

122. The greater likelihood of group activities culminating in criminal conduct than can be expected from individual activity is an untested assumption, although police apparently rely on its truth. The idea that group conduct is more dangerous than individual action is reflected in one context by criminal conspiracy statutes. See Minler, Crminal Law 110-11 (1934).

123. The Philadelphia curfew ordinance prohibits "remaining," defined generally as loitering, and does not reach merely "being" in the proscribed places. PHILADELPhia, Pennsylvania, Code of Gen. Ordinances $\$ \$ 10-302(1)(\mathrm{g}), 10-303(1)$ (1956). Nevertheless, the police do not consistently make this distinction in enforcement, thrusting the task on the minor judiciary for determination when the case comes on for hearing. See text and notes at notes 110-12 supra. 
establishment in the evening. ${ }^{124}$ The ordinance, however, has bestowed significant new power on the police by authorizing them to enter drug stores, restaurants and places of amusement and order juveniles to leave, even though they are not engaged in any unlawful activity at the time. ${ }^{125}$ This power is augmented under the curfew by the provisions for the imposition of a fine upon proprietors who permit juveniles to remain in their establishments after the curfew hour. ${ }^{126}$

In conjunction with enforcement of the curfew against groups of juveniles, there is an absence of uniformity in the treatment given to civic, school or religious functions. No exception is provided in the ordinance for any of these activities, yet the announced policy of the police department is that children returning home from such activities will not be reported as curfew violators, if the district police captain is notified of the function by the sponsoring organization. ${ }^{127}$ However, in at least one instance a district captain reported that he wotild recognize no exception other than those enumerated in the ordinance. His district has had one of the lowest arrest rates in the city, both prior and subsequent to the enactment of the curfew. The rate of curfew violations in his district ranks as one of the highest in the city. This is probably attributable to his personal attitude toward enforcement as evidenced by his stand on the unwritten exception.

\section{Harassment of Individuals}

No instances were noted in which the curfew was used discriminatorily to detain or harass certain identified persons or groups of persons. Some police control devices are susceptible of use to harass or detain persons deemed "undesirable" or "suspicious" by local law enforcement officials. 128 This is particularly true when the ordinance or statute is applicable to a relatively small portion of the population and is sporadically enforced. ${ }^{\mathbf{1 2 9}}$ In contrast, the curfew is not narrowly limited in its application; and enforcement can fairly be described as intensive, with the result that few persons, if any, can legitimately complain that the curfew in Philadelphia is a tool to maintain police surveillance over them as opposed to the juvenile population in general. Moreover, there is little need on the part of the police department to employ the curfew for such purposes. If the police determine that a specific juvenile or group of juveniles is suspected of

124. See Note, Philadelphia Police Practice and the Larv of Arrest, 100 U. PA. L. Rev. 1182, 1201-06 (1952).

125. Philadelphia, Pennsylvania, Code of Gen. Ordinances $\$ 10-302$ (1) (a), 10-303(1) (1956).

126. $I d$. $\S \S 10-305,10-306(3)$.

127. Interview with Inspector Harry J. Fox, July 30, 1957.

128. Typical of these devices is a criminal registration ordinance. See Note, Criminal Registration Ordinances: Police Control Over Potential Recidivists, $103 \mathrm{U}$. PA. L. Rev. 60, 91-94, 102-05 (1954). See also Foote, Vagrancy-Type Laze and Its Administration, 104 U. PA. L. REv. 603, 615-33 (1956); Note, Use of Vagrancy-Type Lawes for the Arrest and Detention of Suspicious Persons, 59 Y YLE L.J. 1351 (1950). 129. Ibid. 
criminal activity, there are sufficient other means of apprehension without having to rely on a curfew violation. ${ }^{130}$ Past experience indicates that the police hold no compunctions about detaining a person without being able to charge him with a specific offense. ${ }^{131}$ Since the range of "delinquent" acts is so broad, it would seem that police practice in arresting juveniles is at least questionable. ${ }^{132}$

\section{B. Judicial Administration}

The Philadelphia curfew ordinance provides no sanction against the juvenile curfew violator, regardless of the number of curfew violations that the juvenile may have amassed. ${ }^{133}$ Parents who "knowingly permit" a second violation by juveniles for whom they are responsible after receiving notice of a prior violation are subject to a minimum fine of five dollars and a maximum fine of $\$ 100 . .^{134}$ Proprietors are subject to a fine of not less than twenty-five dollars nor more than $\$ 300$ for knowingly permitting juveniles to remain in their establishments after the curfew hour. ${ }^{135}$ The magistrates hear and decide all cases of individuals charged with violations. ${ }^{136}$ At the inception of the curfew all cases were brought before the local magistrate sitting in the area of the violator's residence. ${ }^{137}$ However, after a relatively short period this system proved unsatisfactory and unpopular with the magistrates. Magistrates, elected to office, were

130. See text and notes at notes 112-15 supra.

131. Note, Philadelphia Police Practice and the Lawe of Arrest, 100 U. PA. L. Rov. 1182, 1188-1206 (1952). See also Foote, Vagrancy-Type Law and Its Administration, 104 U. PA. L. REv. 603 (1956).

132. See note 114 supra. (1956).

133. Phmadetphia, Pennsylvania, Code of Gen. Ordinances $\$ 10-306(1)$

134. Id. $\S \S 10-304,10-306(2)$. The former section specifies unlawful conduct of parents; the latter specifies the penalties. Viewing the two sections together raises an apparent ambiguity. Section 10-304 makes it unlawful for a parent to "knowingly permit any minor to remain in or upon any public place or any establishment . . ", during the prescribed hours. Section 10-306(2) provides that "any parent who shall violate any provision of $\$ 10-304$ after having received notice of a prior violation shall be fined. . . " It is not clear from the language in the ordinance whether the "prior violation" refers to a violation by the child or by a parent. If the latter, the police would then be in the difficult position of having to determine whether the parent lnowingly permitted the child's initial violation. However, since the purpose of the act is to encourage parents to control their children after the child's initial violation, it would not seem necessary to require that such violation was knowingly permitted.

135. Id. $\$ \$ 10-305,10-306(3)$.

136. There is no provision in the ordinance expressly providing which court shall have jurisdiction over cases involving violators. However, by statute magistrates have power to "hear and determine all actions of debt for penalty for the breach of any ordinance. . ." PA. STAT. ANN. tit. 42, $\$ 291,1058$ (1930). The argument can be made that jurisdiction should be in the juvenile court of Philadelphia, which is the municipal court of Philadelphia. PA. STAT. ANN. tit. 11, \$243(1) (1930). The juvenile court of Philadelphia has "full and exclusive jurisdiction in all proceedings affecting. . . delinquent . . children ... and of all cases of adults - $\therefore$ charged with any act of omission or commission with respect to any child, which act of omission or commission is a violation of any State law or ordinance of any city. ..." Id. \$244 (Supp. 1957).

137. Interview with Raymond Kitty, Assistant City Solicitor, Philadelphia, Pennsylvania, Aug. 22, 1957. 
reluctant to antagonize their constituents over what seemed a trivial matter. As a result many curfew cases were summarily dismissed. It has been reported to the writers that such dispositions resulted even in those cases in which evidence was presented by the City Solicitor clearly indicating violations of the ordinance. Presently, all curfew violation cases in the entire city are heard by one magistrate, a zealous curfew advocate who asserts that his political fortunes will not be allowed to interfere with the performance of his duties. ${ }^{188}$

\section{Procedures in the Magistrate's Court}

A discussion of the procedure followed in the magistrate's court preceeds an examination of that court's disposition of those cases. The proceedings are commenced by calling the names of the persons charged with violating the ordinance. They step to the bar, but are rarely sworn, although even in the magistrate's courts it is statutorily required that witnesses and parties be sworn. ${ }^{139}$ In most instances the violating children attend the hearing although they are not compelled to do so. The current presiding magistrate encourages their attendance because he believes that the lecture which he delivers to them in most cases may do as much good as fining the parents. ${ }^{140}$ The alleged violations by the juveniles are read to the magistrate by an officer of the Juvenile Aid Bureau from the Bureau's copy of the child's police record. Although the evidence is undoubtedly hearsay, ${ }^{141}$ since the hearings are not before a jury and the records can fairly be deemed reliable, this technical defect is not serious. The impractical alternative would be to require the apprehending officer to personally appear and relate the same information that is read from the record, placing an unnecessary burden on an already overworked police force. ${ }^{142}$

138. Also contributing to the reluctance of the magistrates to hear curfew cases is that the hearings are held at an inconvenient hour in the evening.

139. PA. Stat. ANN. tit. 28, $\$ 251$ (1930). There is no requirement that a stenographic record of the prceedings be kept. PA. STAT. ANN. tit. 42, \$§ 1111, 1137 (Supp. 1957).

140. The prceedings are informal, and often as a result of the magistrate's remarks they lack the dignity expected to attend judicial proceedings. Thus, when the mother of a child with a long arrest record could not attend the hearing because she was ill the magistrate remarked, "If I had a boy like you I'd be sick too." To a boy with ten arrests the judge said, "Sonny, you win the gold cup for tonight." To another, "If she'd bang you along the mouth once in a while, you'd be all right!" And to another, "You crazy or something?"

The magistrate constantly uses the threat technique with both children and their parents. Although he does not have the authority to commit juveniles to an institution, PA. STAT. ANN. tit. 11, $\$ 244$ (Supp. 1957), he often threatens to "put him away" the next time he violates the curfew. Lacking jurisdiction over juveniles, the magistrate could recommend to the Juvenile Aid Bureau that the child be brought before the juvenile court as a delinquent for having violated the curfew. There is no record of any such recommendation ever having been made, nor is there any record of the Juvenile Aid Bureau having taken such action on its own initiative.

141. See McCormick, Evidence $\$ \S 281,283$ (1954).

142. The doctrine has been asserted that the rules of evidence are inapplicable to magistrate's hearings. Orfield, Criminal Procedure From Arrest to Appeal 88 (1947). However, it is not clear whether a distinction is made between the dual 
On the other hand, a significant defect noted in the conduct of the hearings is that parents are adjudged guilty and sanctions imposed without proof by the city of all the elements necessary to establish guilt and apparently without giving fair consideration to the evidence of statutory defenses introduced by the defendants. For example, the ordinance subjects to fine only those parents who have received notice of a prior violation by the child..$^{143}$ Yet in none of the cases observed ${ }^{144}$ did the prosecution introduce any evidence of prior notification. ${ }^{145}$ The fact that a previous violation was committed is no indication that the parent was informed of it. Although the ordinance directs the Juvenile Aid Bureau to notify the parents of every violation, ${ }^{146}$ there is evidence that the requirement is not fully performed: of the 6,973 curfew violations reported in 1957 the Bureau claims to have sent notices to parents in only 6,143 instances. ${ }^{147}$ It would seem incumbent upon the magistrate to discharge those cases in which proof of this requisite element of the offense is not made.148 Not only is it legally demanded of the magistrate, whose responsibility in these cases is accentuated by the fact that most defendants are unrepresented by counsel, but his failure to enforce the notice requirement tends to frustrate the parental responsibility provision of the ordinance. Parents are not to be penalized but to be encouraged to control the conduct of their children, which encouragement the City Council intended should first be attempted by way of a warning notice. A real threat of dismissal by the magistrate for failure to prove notice would operate to insure official conformity with the directives of the ordinance.

As for the defenses available under the law, a parent might attempt to prove that the child did not "loiter, idle, wander, stroll or play" in a

functions performed by a magistrate: (1) to determine whether there are reasonable grounds for holding an arrested person for further proceedings, and (2) to determine guilt or innocence in those cases in which he has summary jurisdiction. As a practical matter, insistence on strict adherence to the rules of evidence would be incapable of implementation since only two of Philadelphia's twenty-eight magistrates are attorneys. See Note, Prelinimary Hearings on Indictable Offeruses in Philadelphia, 106 U. PA. L. REV. 589, 592-93 (1958).

143. Philadelphia, Pennsyluanta, Code of Gen. Ordinances $\$ 10-304,10-306$ (2) (1956).

144. During the months of July, August and September 1957, over 100 cases were personally observed.

145. The few cases in which evidence of notice did appear were those in which the information was volunteered by the defendants.

146. Philadelphia, Pennsylvania, Code of Gen. Ordinances $\$ 10-306(1)$ (1956).

147. To some extent the failure to send notice can be attributed to the fact that a number of the juveniles reported as curfew violators do not reside within Philadelphia. Of the 2,051 violations in 1955, children residing other than in Philadelphia accounted for 94 . In 1956, 161 of the 2,990 curfew violations were committed by non-residents. Nonetheless, the statistics indicate that a significant number of curfew violations by juveniles resident in Philadelphia are not reported to parents.

148. Proof of notice would not impose an onerous burden on the city. The simple expedient of sending notice by registered mail with "return receipt requested" would resolve the administrative problem of the police and settle the issue before the magistrate. 
public place or establishment after the curfew hour ${ }^{149}$ but was proceeding towards a specific destination, or that the parent did not "knowingly permit" the child's second violation, ${ }^{150}$ or that the child's activities were within one of the express exceptions, e.g., that he was engaged in an errand "or other legitimate business" at the parent's behest..151 The contacting officer is not present to testify to the facts which he observed, and no inference as to the juvenile's activities may properly be drawn from the bare fact of his report, since, as previously discussed, ${ }^{152}$ the police indiscriminately report children discovered on the streets after-hours without consideration of whether the alleged violator was "remaining" (loitering) or "being" outdoors, or of the children's explanations for their presence. Thus the defendant's or the child's explanation of the fact circumstances is opposed by no other evidence and subject only to a determination of their credibility by the magistrate. None would contend that efficient enforcement of the ordinance could be achieved by the magistrate's giving conclusive effect to the undisputed testimony of everyone of these interested parties, but the impression which the writers received was that no genuine consideration was given to them at all, defendants and witnesses often being silenced before they had an adequate opportunity to complete their presentation. Even the City Solicitor's occasional recommendation that a defense be sustained is usually disregarded. To the writers' experience, the only contention that has been successfully maintained by parents is that the juvenile was over-age at the time of apprehension.

Whatever the magistrate's mental decisional processes on the question of credibility, judgment ought not to be rendered before defendants have had an opportunity at least to appear to be heard, and it certainly would be a happier result if greater patience and consideration were expended in an attempt to more realistically carry out the directions of the ordinance. Not only does apparent disregard of the express legislative delimitation of the conduct prohibited, particularly the exceptions permitted and the definition of "remaining" in a public place or establishment, lead to popular resentment of the curfew, but it may well be crucial to the issue of its constitutionality. ${ }^{153}$

\section{Case Disposition}

Proprietors' liability has been invoked only once since the inception of the curfew, that fine being for twenty-five dollars. During the period from December 6, 1956 (when a single magistrate began to hear all cases),

149. Phicadelphia, Pennsylvania, Code of Gen. Ordinances $\$ \$ 10-302(1)(g)$, $10-303$ (1) (1956).

150. Id. $\$ 10-304(1)$.

151. $I d . \S 10-303(2)$.

152. See text at notes 110-12 supra.

153. See text and notes at notes 180-91 infra. 
to July $11,1957,190$ cases of parental liability were heard. ${ }^{154}$ Thirty-seven of these cases were discharged; in eighty-one, court costs only were imposed; in seventy, fines plus costs were levied; and two cases were con-

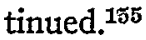

Of the thirty-seven cases discharged, in seven there was no explanation for their disposition recorded. Twelve were discharged on the ground that the parents had moved, and four were on the ground of no service of process. ${ }^{150}$ Only one of the thirty-seven cases was discharged on a finding that there had been no violation on the part of the parent. In that case the juvenile was over the age limit at the time of his alleged second violation. The disposition of all but two ${ }^{157}$ of the remaining thirteen cases in the "discharged" category indicates that the magistrate tends not to impose penalties upon parents when he believes that such action will not effectuate the purpose of the parental responsibility provisions of the ordinance, i.e., induce parents to control their children. In eight of these cases the juvenile violators were incarcerated in a correctional institution at the time of the hearing; in two cases the juveniles were in the armed service; and in one case the violator had been married prior to the hearing. Although this exercise of discretion may be theoretically justifiable, it is legally indefensible in the view of the plain prescription of the ordinance that a penalty is to be imposed in all cases where the necessary proof has been established regardless of the probable lack of deterrent effect on the parents. ${ }^{158}$ Furthermore, it may be argued that even in the case of those children who have strayed so far from the paths of proper conduct as to become subject to personal sanctions imposed by the state juvenile criminal law, a fine levied on the parents may tend to impress them with their own responsibilities in the matter, encouraging them to greater control over

154. This sample of 190 cases must be distinguished from those cases, previously discussed, which were personally observed by the writers. The information regarding these 190 cases was gathered from the records of the City Solicitor of Philadelphia.

155. Judicial Disposition of Alleged Curfew Violations by Parents-

December 6, 1956 Through July 11, 1957

Disposition of Parent

1) Discharged

2) Costs Only

3) Fine \& Costs

(a) $\$ 5 \&$ Costs

(b) $\$ 10 \&$ Costs

(c) $\$ 25 \&$ Costs

(d) Other Amounts

4) Continued

Total
The Child's Number of Violations

\begin{tabular}{lc}
\multicolumn{2}{c}{ of Violations } \\
\hline 2 & More Than 2 \\
\cline { 1 - 1 } & 10 \\
63 & 18 \\
39 & 31
\end{tabular}

(a) 25

(b) 5

(c) 8

(d) 1 (a) 13

(b) 8

(c) 9

(d) 1
Total

37

81

131

59

190

156. The extent to which the former category encompasses the latter could not be determined. It is probable that in at least some of the twelve instances categorized as "moved," the fact was uncovered on the constable's return of process unsatisfied.

157. In one of these cases the parent was hospitalized, and in the other the juvenile no longer lived with his parents but resided with foster parents. (1956).

158. Philladetphia, Pennsylvania, Code of Gex. Ordinances §10-306(2) 
their offspring when they are released from the correctional institutions. There is no reason to believe that incarceration indicates incorrigibility or inability on the part of the parent to control.

One hundred fifty-one of the 190 cases resulted in the imposition of some sanction. ${ }^{159}$ In eighty-one cases of this group (53.7 per cent), costs only were imposed..$^{160}$ Although the magistrate is permitted to exercise discretion within the limits prescribed by the ordinance in fixing the amount of fine, there is no authority for failure to impose at least the minimum fine on a finding of guilty. Since violation on the part of the parent was expressly found in each of these cases, it would seem that the magistrate had no legal choice but to impose the minimum fine rather than assess costs only. ${ }^{161}$ Of the remaining seventy cases in which fines were levied in addition to payment of court costs, thirty-eight were fines of $\$ 5$, thirteen were fines of $\$ 10$, seventeen were fines of $\$ 25$, one was $\$ 50$, and one $\$ 2.50 .162$

The variations in penalties meted out may be attributed to several considerations. First, some of the cases were not heard until after more than two violations had been reported against the juvenile. ${ }^{163}$ Second, in the event of a parent's second hearing (in which case the child must have accumulated at least three curfew violations) the magistrate invariably imposed a fine in addition to costs, with the fines tending generally to be more severe than for those parents having a first hearing after their child's third violation. ${ }^{164}$ Other considerations affecting the determination of the penalty to be imposed include the attitude of the parent and the juvenile at the hearing, the existence and extent of the child's prior police record (of which curfew violations are a part), and the magistrate's general estimate of whether the parents could control the conduct of their child; i.e.,

159. See note 155 supra.

160. In two of these cases, the juvenile was in a correctional institution at the time of the hearing. Imposition of a sanction in this situation does not appear to be present practice, however. The following eight cases in which the curfew violator was incarcerated at the time of hearing resulted in discharge. See text below note 157 supra.

161. In a few of the cases personally observed, hence not within the sample under immediate discussion, the magistrate imposed costs on the parents even though no violations were found. Under earlier Pennsylvania law all cases of summary convictions in which the evidence was not sufficient to convict and the action was dismissed, costs were paid by the county. PA. Stat. AnN. tit. 42, $\$ 211$ (1930). However, this statute was repealed by two later acts: (1) The Minor Judiciary Fee Bill, Pa. Stat. ANN. tit. 42, $\$ \$ 216-21$ (Supp. 1957) (applicable to all cities except those of the first class, and providing for the payment of costs by the county in the event of a dismissal); and (2) Magistrates Fee Bill of Cities of the First Class, PA. STAT. ANN. tit. 42, $\$ \$ 231-35$ (Supp. 1957) (contains no provision for the payment of any costs by the county). Since Philadelphia is a city of the first class, the practice of imposing costs on dismissed parties in curfew cases seems to be within the statute. However, it is questionable whether this practice would satisfy the requisites of constitutional due process of law.

162. In view of the minimum fine of $\$ 5$ prescribed in the ordinance, see text at note 134 supra, the imposition of a fine of a lesser amount is improper.

163. See note 155 supra.

164. Of the 190 cases in the sample, eight involved parents who had had a prior hearing for violation of the ordinance. These cases were disposed of as follows: three discharged, one fine of $\$ 5$ plus costs and four fines of $\$ 25$ plus costs. 
whether a fine would be useless. While all these factors contribute to the choice of sanction, it is the writers' impression that in most of the cases in which costs only were assessed, the action is the result of the magistrate's ad hoc determination that even though the juvenile is a curfew violator, he or she is not likely to engage in criminal activity. Since it cannot be denied that the curfew does capture a large number of juveniles who would otherwise not be involved with the police, there is little issue that can be taken with the magistrate's basis for the exercise of his discretion, provided he exercises that discretion within the confines prescribed in the ordinance.

Although many of the deficiencies in the administration of the Philadelphia curfew ordinance which emerge from the above discussion are identical with those that exist in any summary trial or hearing, others are peculiar to this problem and subject to cure. More specifically, the only devices available to the magistrate in effecting the purpose of the ordinance are the fine and the public lecture. In many cases these may be adequate to encourage parents to exercise greater control over the activities of their children, but it would seem that a transfer of jurisdiction over these cases to the juvenile court would produce more favorable results in all cases. The investigative facilities of that court would be of invaluable aid in determining the true facts of each case and in determining if the parents are capable of controlling their children in the future. Further, if it were discovered that parental control was lacking, the social agencies affiliated with the juvenile court could be called upon for additional assistance. Since this is the system utilized by the state to deal with anti-social acts of juveniles, it is not unreasonable to urge that acts which create a likelihood of anti-social conduct should be treated within the same system.

\section{Evaluation}

Any evaluation of juvenile curfew legislation necessarily must attempt to balance the effectiveness of the device in achieving its ends with the likelihood of abuse and the restraint imposed on individuals' freedom of locomotion. These considerations are relevant to a determination not only of the social desirability of such legislation but also of its constitutional validity. In this section emphasis is placed on the former problem, accompanied by some observations on the constitutional issue.

\section{A. Police Control of Groups of Juveniles}

Ultimately, there is only one basic objective of curfew legislation: to reduce the incidence of juvenile criminal activity. If juveniles are constrained to remain at home in the evening, the opportunity and temptation to commit crime is diminished. Further, the curfew implements the ability of the police to break up groups and gangs of children congregating away from home at night in order to prevent any consequential illegal endeavor. ${ }^{165}$

165. See text and notes at notes 123-26 supra. 
The latter use of the curfew has been undertaken by the Philadelphia police department. The police report that it has aided considerably in the attempt to control nighttime accumulations of juveniles, but the extent of the impact of this device on the over-all criminal picture is incapable of determination. ${ }^{166}$ Nevertheless, the curfew removes the technical strictures of the law of arrest by permitting the police to take action prior to what reasonably appears to be an attempted criminal act. ${ }^{167}$ In addition, those curfew ordinances which extend their prohibitions to eating places and other enclosed establishments and which provide penalties against proprietors permitting children to remain there after the curfew hour are an aid to the self-policing of such establishments by the proprietors. This is true even though the sanction is sporadically invoked as in Philadelphia where only one such instance was noted. Proprietors can fall back on the potential sanction against themselves as a reason for excluding juveniles without incurring their disfavor.

Certain qualifications on the above assessment of the value of a curfew as a control device need to be made. ${ }^{168}$ A word or gesture on the part of the police oftentimes is a more effective deterrent than is the threat of arrest after questionable activities have begun. The existence of general loitering ordinances in many municipalities technically provides the police with the same authority to act as do the prohibitions in many curfew ordinances. ${ }^{169}$ These considerations tend to diminish the utility and need for a curfew. However, those curfew ordinances which prohibit "being" in certain designated places after the curfew hour are on their face broader in scope than loitering statutes, ${ }^{170}$ as are those curfew ordinances which extend their prohibitions to eating places and other enclosed establishments. ${ }^{171}$ In addition, even though a curfew ordinance does not prohibit "being," enforcement, if intensive, has the effect of transforming the ordinance into a "being" type prohibition. The distinction between "being" and "loitering" is more semantic than real at the enforcement level and similarly, on the basis of the Philadelphia experience, on the judicial level. ${ }^{172}$ Moreover, an ordinance labelled a "curfew" popularly conveys the idea that it prohibits "being" regardless of the specific language in the ordinance. This

166. See text and notes at notes 173-79 infra.

167. See text and notes at notes 110-15 supra. See also The Legal Intelligencer (Philadelphia), June 25, 1958, p. 1, cols. 1-2.

168. Although the police are technically without authority to act affirmatively in the absence of what reasonably appears to be an attempted criminal act, actual practice indicates that in many instances the police are not constrained from interfering in activities they consider undesirable by considerations of the legality of an arrest. But the fact that police exceed existing authority should not preclude a conferral of authority to act in those situations where as a matter of legislative policy such authority should exist.

169. Philadelphia has a loitering ordinance limited in its applicability generally to conduct in or about public transportation facilities. PhIladelphia, Pennsylvania, Code of Gen. Ordinances $\$ 10-603$ (1956).

170. See text and note at note 43 supra.

171. See text and note at note 52 supra.

172. See text and notes at notes $149-53$ supra. 
popular conception of a "curfew" is likely to be reflected in its enforcement both by police and by parents. Thus, the curfew encompasses a wider range of conduct than does a criminal loitering or similar type ordinance thereby providing an increment to existing police authority.

\section{B. Effect on the Incidence of Juvenile Crime}

The potential impact of the curfew on the totality of juvenile criminality is necessarily limited by the fact that it is directed solely at noctural juvenile crime. However, the amount of such crime is apparently great; the peak number of complaints received by the Juvenile Aid Bureau occur between the hours of 10:00 p.m. and 12 midnight. 173 This rough index of the incidence of juvenile criminal activity indicates that an effective curfew would make a substantial contribution to the alleviation of juvenile criminal activity. But an accurate determination of the effectiveness of the curfew in achieving its objective is, as a practical matter, impossible to ascertain. First, there is no accurate measure of the incidence of criminality during a given period of time, since a substantial proportion of crimes committed are undetected. ${ }^{174}$ Further, the assumption that the number of detected crimes bears a constant relation to the actual crime rate is hazardous because the number of recorded crimes varies with changes in police practice, court policies and public opinion. ${ }^{175}$ But even if recorded crime were a reliable index of total criminal activity, there is no method of establishing the proportion of recorded crime that is committed by juveniles. The initial classification by age occurs in arrest statistics which are necessarily imprecise indices of criminal activity. The number of arrests, like the number of recorded crimes, varies with police and judicial policy and public opinion. Moreover, many arrested persons are later found not to be

$\begin{array}{ccr}\text { 173. Complaints by Hour-January to December Inclusive } & \\ \text { Hour } & 1955 & 1956 \\ 12: 00 \text { noon } & 729 & 846 \\ 1: 00 \text { p.m. } & 518 & 739 \\ 9: 00 & 900 & 1,158 \\ 10: 00 & 848 & 713 \\ 11: 00 & 803 & 795 \\ 12: 00 \text { midnight } & 674 & 675 \\ 1: 00 \text { a.m. } & 760 & 822 \\ 2: 00 & 832 & 1,068 \\ 3: 00 & 939 & 1,153 \\ 4: 00 & 805 & 1,003 \\ 5: 00 & 958 & 1,389 \\ 6: 00 & 706 & 840 \\ 7: 00 & 779 & 920 \\ 8: 00 & 799 & 973 \\ 9: 00 & 992 & 1,144 \\ 10: 00 & 1,020 & 1,280 \\ 11: 00 & 1,046 & 1,377\end{array}$

174. For a discussion of the difficulties in arriving at a significant index of criminality see Sutherland \& Cressey, Princtples of Crmminology 25-38 (5th ed. 1955).

175. $I d$. at 25 . 
answerable for the acts charged against them. This is particularly true of juveniles who tend, probably, more so than adults, to commit offenses as groups or gangs. This leads to mass arrests, even though only one or two members of the group ultimately will be found responsible. ${ }^{176}$ But accepting arrests as a meaningful criterion of the quantum of criminal activity, there is no method of establishing a correlation between curfew enforcement and changes in the pattern and number of arrests. There is no evidence of causal relation between the two, for any assertion that such a relation exists must take cognizance of the multifarious factors influencing the incidence of criminality. ${ }^{177}$ When the uncertainty of the correlation between the curfew rate and the arrest rate ${ }^{178}$ is coupled with the weaknesses of the arrest as determinative of the incidence of juvenile criminality, the only reasonable conclusion is that there is no certainty that curfew enforcement reduces juvenile nocturnal crime.

Although not provable statistically there are a few generalizations about the effectiveness of a curfew that may be offered. Curfews probably are not an aid in crime detection. Curfew violations are uncovered in the course of police patrol of neighborhoods and are a routinized matter. In those cases in which apprehension for curfew violation is accompanied by an arrest ${ }^{179}$ it is likely that the arrest would have been made in any event and that the curfew violation was appended when the arrested juvenile was discovered to be in the age group subject to the curfew. On the other hand, the curfew is an aid to police control of the activities of groups or gangs of juveniles, conferring authority on the police to interrupt juvenile nocturnal activities before any wrong has occurred.

Viewing the potential impact of the curfew on nocturnal juvenile crime, certain conclusions seem evident. Those children most likely to be deterred by the ordinance from remaining outdoors after the curfew hour are those least likely to engage in criminal activity. Conversely, those least likely to be deterred are the same children who most probably would engage in criminal activity. There is, however, one group, those children on what might be termed the "fringe" of the delinquent community, who

176. Sellin, Observations on Statistics of Juvenile Delinquency, in CRME PREvention Assoctation of Philadelphia, Report 8 (1956).

177. Sutherland \& Cressex, op. cit. supra note 174, at 138-219.

178. Several statistical comparisons are cited as evidence that the curfew has the effect of lessening juvenile criminal activity. In 1957, the year of the curfew's most intensive enforcement, juvenile arrests declined from 10,270 in 1956 to 9,027 , a decrease of $12.1 \%$. Analysis by police district tends to show the same result. In all but six of the twenty-three districts the arrest rate went down whereas the curfew rate increased in all but two districts. See note 118 supra. While these arguably support a contention that curfew enforcement reduces juvenile crime, a comparison of similar figures for the years 1955 and 1956 casts doubt on the validity of the claim. For example, the number of juvenile arrests increased from 7,953 in 1955 to 10,270 in 1956 , an increment of $29.1 \%$. While in the same period curfew violations increased from 2,051 in the last eleven months of 1955 to 2,990 in the twelve months of 1956, an increment of $33.6 \%$ on the basis of the average number of violations per period.

179. In 1955 of the 2,051 curfew violations 273 were accompanied by arrests. In 1956 arrests were made in 398 of the 2,990 incidents of curfew violation. In 1957 in the 6,973 cases of curfew violation only 266 were appended to arrests of the juvenile. 
would be deterred from remaining away from home at night by their parents if the threat of a sanction were available against the parents. Further, the "spur-of-the-moment" nocturnal crime resulting from group or gang action may be lessened by the fact that late-at-night accumulations of juveniles are easily detected and can be dispersed under the curfew. An underlying assumption in all these instances, except the last, is that the likelihood of criminal activity decreases as the amount of control exercised by parents over the activities of the juvenile increases; the greater the breakdown in the social structure of the family unit, the greater the chance of anti-social behavior by its members. The curfew might be effective to the extent that parents can be induced, under pain of fine, to exercise their control where they otherwise might tend to allow their children a freer rein. Viewing the curfew as having such limited objectives, rather than as a panacea, it would seem that even though persons may dispute its social desirability, it certainly is not irrational for a legislative body to experiment with it in an attempt to stem an increase in juvenile criminality.

\section{Constitutional Validity}

In doctrinal terms, a state or municipal legislature has the power to limit any individual right without violating the due process clause of the fourteenth amendment or its state counterparts, if the limitation is reasonable in view of the need of the state, roughly measured by the gravity of the evil to be corrected and the importance attributed to the right invaded..$^{180}$ Substantive due process demands, as a minimal requirement on legislative enactments, that there be a rational relation between the end sought and the means chosen. ${ }^{181}$ However, while this relationship between ends and means may of itself be sufficient to withstand constitutional attack in the area of economic regulation, ${ }^{182}$ the test is generally more stringent in at-

180. See Near v. Minnesota, 283 U.S. 697, 708 (1931) ("Liberty of speech and of the press is not an absolute right, and the state may punish its abuse."). Cf. Schenck v. United States, 249 U.S. 47, 52 (1919) ("The most stringent protection of free speech would not protect a man in falsely shouting fire in a theater and causing a panic.").

Assuming that state and federal due process clauses have the same declared substantive content, state courts theoretically are freer than federal courts to invalidate state action on due process grounds. Any reluctance on the part of federal courts to strike down state legislation under the due process clause, induced by considerations of federal-state relations, is lacking in state courts confronted with constitutional challenges to state action.

181. See Schware v. Board of Bar Examiners, 353 U.S. 232, 239, 246-47 (1957); Slochower v. Board of Educ., 350 U.S. 551, 555-56, 558-59 (1956).

182. The test for the validity of state regulation of economic interests has been described as requiring a substantial relation between the means chosen and the end sought. Cities Serv. Gas Co. v. Peerless Oil \& Gas Co., 340 U.S. 179 (1950). In this case the Court stated: "Like any other legislation, a price-fixing order is lawful if substantially related to a legitimate end sought to be attained. Nebbia v. New York, 291 U.S. 502 (1934) and cases therein cited." Id. at 186. Dicta in cases subsequent to Nebbia v. New York had indicated that the standard of relationship between means and end in economic cases was that there be only a "rational basis." See West Virginia State Board of Educ. v. Barnette, 319 U.S. 624, 639 (1943). See also Thomas v. Collins, 323 U.S. 516, 527 (1945). 
tempts to validate legislative limitations on the "indispensable democratic freedoms secured by the First Amendment." 183 In the latter situation the legislative restraint "must have clear support in public danger, actual or impending." 184

While the interests of those persons affected by a curfew are not within the scope of the rights described in the first amendment, made applicable to the states through the fourteenth, restraints on individual liberty should likewise be judged by a standard more severe than that applied to economic regulation. Considering the type of curfew ordinance currently prevalent, two private interests are identifiable. The first is the interest of the juveniles, the primary subjects of the curfew, to be free to venture away from home. Whether this interest on the part of juveniles be characterized as the "right of locomotion" or as a "necessary ingredient of the integrity of the individual" or by some less stirring term, undoubtedly it is within the ambit of the constitutional protection afforded by the word "liberty" in the fourteenth amendment. ${ }^{185}$ The exercise of an unlimited power to confine individuals to their homes would strike to the core of the democratic ethic. The fourteenth amendment presumably affords protection against the exercise of such a power, even though there might be a rational basis for an enactment requiring persons to remain at home while not at work or at school as a means of reducing the incidence of criminality in public places. To hold otherwise would be to sanction the adoption of measures that would be indistinguishable from those practiced in police states. The second identifiable interest is that of the parents, legally responsible for violations by juveniles under most curfew ordinances, in being free from state control and direction of the manner in which their juvenile children are to be regimented. This latter interest is, to a large extent, derivative of the interest of the juveniles noted above, and a resolution of the validity of the curfew with respect to juveniles which is adverse to the state or municipality would be determinative of the issue of validity with respect to adults. Although it does not necessarily follow, it would seem that, conversely, the imposition on parents of responsibility for the nighttime whereabouts of their children under a curfew constitutionally valid as to the children should not be unlawful. ${ }^{186}$

Judicial guidance on the particular constitutional issue involved in curfew regulation of juveniles is sparse. Although there is some authority

183. Id. at 530 .

184. Ibid.

185. While there are no federal cases on point, state cases indicate that such an interest is cognizable under state due process clauses. See note 188 infra. In other contexts the Supreme Court has given recognition and protection to interests analogous to that in the instant case. Cf. Lambert v. California, 355 U.S. 225 (1957) (criminal registration) ; Edwards v. California, 314 U.S. 160 (1941) (right of persons to freely enter and take up residence in another state): Cf. also Kent v. Dulles, 357 U.S. 116, 125 (1958) (right to travel in foreign countries).

186. See Comment, 1 VIIL. L. Rev. 51, $57-58$ (1956). 
concerning the control of the free movement of adults, ${ }^{187}$ the interest of children in being abroad during the night hours is not nearly so important to the social, economic and healthful well-being of the community, and there is, therefore, reason to believe that this legislation will receive different judicial consideration. The federal courts, including the Supreme Court, have not yet been presented with the problem in any case. The scarce authority that exists, represented by a few state court decisions, ${ }^{188}$ affords little help in analyzing the constitutional problem. The particular ordinances which were approved or rejected in those cases do not contain features which might meaningfully serve as significant points for distinguishing the valid from the invalid regulatory measures. In those cases in which curfews were found invalid, for example, emphasis was frequently placed on the statutory language used to define the illegal conduct. Thus, a prohibition of "remaining or loitering" has been sustained and distinguished from a prohibition of "being" on the streets. ${ }^{189}$ In view of the generally synonymous interpretation given to these terms at the enforcement and administrative levels, ${ }^{190}$ a judicial determination on this ground seems fallacious.

The basic inquiry of whether the local need for a curfew limitation is sufficiently great to be a reasonable governmental restraint in view of its serious invasion of individual liberties has not been articulately considered by any court. The opinions, in the main, sound in the stark conclusions of "reasonableness" or "unreasonableness" without shedding light on the genuine bases for their decisions. It would seem, however, that there are several significant factors relevant to this determination which, unlike judicial intuition, may be isolated and subjected to some degree of factual exploration. Without judicial articulation of the specific considerations which indicate unreasonable, and therefore unconstitutional, governmental restrictions of juveniles, municipal legislatures are without any direction to aid them in considering their own local conditions to accurately determine which type of curfew ordinance, if any, they might properly enact. An attempt will here be made to suggest some of the factors which the writers

187. E.g., Kent v. Dulles, 357 U.S. 116 (1958) ; Lambert v. California, 355 U.S. 225 (1957); Hirabayashi v. United States, 320 U.S. 81 (1943) (military curfew imposed on persons of Japanese ancestry living on West Coast during World War II) ; Edwards v. California, 314 U.S. 160 (1941).

188. Constitutional : People v. Walton, 70 Cal. App. 2d 862, 161 P.2d 498 (App. Dep't 1945); Baker v. Borough of Steelton, 17 Dauphin County $\mathrm{R} .17$ (Pa Q.S. 1910). Unconstitutional: Alves v. Justice Court of Chico Judicial Dist., 148 Cal. App. 2d 419, 306 P.2d 601 (Dist. Ct. App. 1957); Riley v. City of Miami, Chancery No. 198087, Cir. Ct. of 11th Cir. of Fla., April 5, 1957; Ex parte McCarver, 39 Tex. Crim. 448, 46 S.W. 936 (1898). But cf. Guidoni v. Wheeler, 230 Fed. 93 '(9th Cir. 1916) (upholding an ordinance of Juneau, Alabama, which forbade all idle or dissolute persons or those with no visible means of support from wandering on the streets after 11 p.m.).

189. E.g., compare People v. Walton, 70 Cal. App. 2d 862, 151 P.2d 498 (App. Dep't 1945), writh Alves v. Justice Court of Chico Judicial Dist., 148 Cal. App. 2d 419, 306 P.2d 601 (Dist. Ct. App. 1957).

190. See text and notes at notes $43-46$ supra. 
believe are fundamental to a rational evaluation of the constitutional problem.

In broad outline, the question might be phrased in terms of weighing the seriousness of the evil to be prevented and the need for this type of measure to effectuate the cure, against the gravity of the invasion of the individual liberties of the persons restricted by the ordinance. The evil which these laws are designed to correct is readily subject to demonstration. Should a relatively low rate of juvenile crime be shown to exist in a particular community, the need for so severe a general popular regulation might immediately be disproved. Even if the amount of juvenile criminal activity is of major proportions, the need for curfew control is almost impossible of proof. Existing police statistics, as previously discussed, disclose no definitive correlation between the enforcement of a curfew and the diminution of nocturnal juvenile anti-social conduct. ${ }^{191}$ This aspect of the problem, however, might be accepted on its theoretical grounds alone, i.e., that keeping children off the street is likely to have some relation to the discovery of those juveniles who have embarked on a criminal escapade. It might well be proper to permit a legislature to experiment with such a procedure were the attendant injuries not too severe. In end result the considerations on the other side of the balance, i.e., the extent of the invasion of the individual liberties and the harshness of the restriction on those subject to it, will be more determinative of the issue. These factors, by contrast, would appear to be subject to some greater degree of probative exploration. The time at which a curfew should commence, for example, will be determined in part by what police statistics reveal to be the significant hours of crime commission, but in even greater measure should be determined by the community sense of the proper time for cessation of outdoor juvenile social activity. Parents of diverse cultural backgrounds might well disagree on the amount of evening social activity which is desirable for their children in order to mold mature and healthy adult personalities. Certainly children might be turned indoors at a relatively early hour in, for example, a community primarily populated by parents of Pennsylvania Dutch background when a similar regulation would be properly considered overburdensome in a metropolitan area where teen-age evening social activities are parentally encouraged. Furthermore, an inquiry into the indoor recreational facilities available to the local juvenile residents would seem to be of crucial importance. In a city with overcrowded or slum areas, the character of the actual housing facilities might be such that there simply is not adequate living space indoors to permit children, required to remain at home some hours before bedtime, to healthfully occupy their timeparticularly in the summer when school vacations permit even later waking hours. In such a community the provisions of the curfew might be entirely intolerable and unreasonable while the identical law, providing the same hours and applicable to the same age groups, would be far less subject to

191. See text and notes at notes 174-78 supra. 
attack in a wealthy suburban area where most homes are equipped with playrooms, television sets and the like. Similarly, the character of public recreational facilities provided in a particular community would have direct bearing on the reasonableness of a requirement that children remain in their homes in the evening. The danger of anti-social activity is far less where juveniles may constructively occupy themselves away from home than where they may only roam the streets. Consideration of the existence of such facilities would likewise be relevant to the determination of the nature of the exceptions from the curfew restriction which must reasonably be permitted.

Although these considerations, and others like them, would seem essential to a meaningful evaluation of the constitutionality of curfew ordinances, no court has yet articulately discussed them when treating the problem. With judicial authority in such a state, one can only speculate as to how a court might decide this fundamental issue of validity should it be adequately presented by counsel and seriously considered by the court.

H. $L$.

R. R. O. 


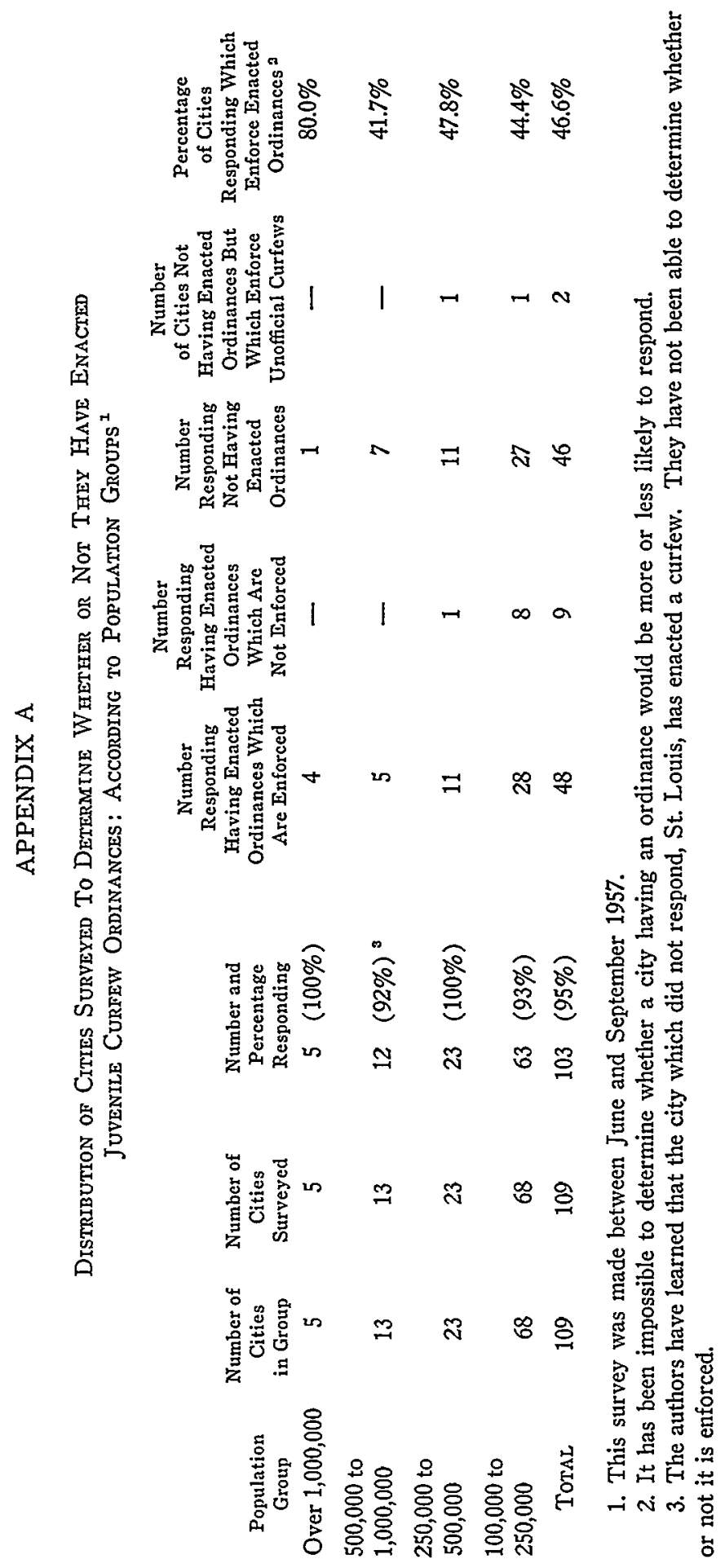

